Precipitation, Streamflow,

and Major Floods at Selected

Sites in the Gila River

Drainage Basin above

Coolidge Dam, Arizona

GEOLOGICAL SURVEY PROFESSIONAL PAPER 655-B 

Precipitation, Streamflow,

and Major Floods at Selected

Sites in the Gila River

Drainage Basin above

Coolidge Dam, Arizona

By D. E. BURKHAM

GILA RIVER PHREATOPHYTE PROJECT

GEOLOGICAL SURVEY PROFESSIONAL PAPER 655-B

An analysis of the hydrologic variables and

relations affecting drainage of the Gila River

Phreatophyte Project area

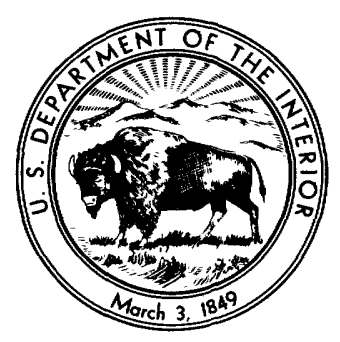

UNITED STATES GOVERNMENT PRINTING OFFICE, WASHINGTON : 1970 
UNITED STATES DEPARTMENT OF THE INTERIOR

WALTER J. HICKEL, Secretary

GEOLOGICAL SURVEY

William T. Pecora, Director

For sale by the Superintendent of Documents, U.S. Government Printing Office Washington, D.C. 20402 - Price 50 cents (paper cover) 


\section{CONTENTS}

Abstract

Introduction.

Purpose and scope of this report.....

Acknowledgments .

Description of the Gila River basin above Coolidge Dam.

Precipitation.

Types of airmasses ........

Storm types

Variability

Streamflow.

Seasonal types.

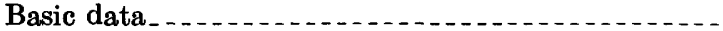

Frequency and variability of daily and seasonal Gila River flow through Safford Valley.

Long-term trends.

Precipitation-runoff relations
Streamflow-Continued

Water loss in Safford Valley

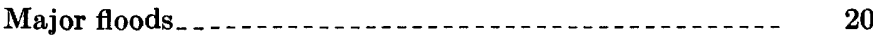

Flood of February 22, 1891 _...

Flood of September-October 1895 _..

Flood of October 1896

Flood of January 1905

Flood of November 28, 1905 ...

Flood of December 3, 1906........ 24

Floods of December 20, 1914, and January 30, 1915

Floods of January 18-20 and 29, 1916

Flood of October 14-15, 1916

Flood of September 29-October 1, 1941_._. . . . . 25

Floods of December 21-24 and December 30-31, 1965

Summary

References cited . . 32

\section{L L U S T R A T I O N S}

FIGURE 1. Map showing location of precipitation gages and stream-gaging stations

2. Graphs showing progressive 10-year average of seasonal precipitation

3. Typical hydrograph of winter flow

4. Typical hydrograph of summer flow

5-16. Graphs:

5. Duration curves of summer flow

6. Duration curves of winter flow

7. Progressive 10-year average annual flow

8. Relation of winter runoff and average winter precipitation

9. Double-mass relation of measured winter runoff versus computed winter runoff

10. Double-mass relations of measured summer runoff versus computed summer runoff . ..........

11. Double-mass relation of measured streamflow at head of Safford Valley and that at San Carlos.-

12. Progressive 10-year average reduction in annual streamflow

13. Relation of annual streamflow at head of Safford Valley to that at San Carlos.........

14. Double-mass relation of computed annual streamflow and measured annual streamflow

15. Relation of summer streamflow to size of basin

16. Annual floods of record in the Gila River basin

17-21. Photographs:

17. Floods at Clifton, 1905-16

18. Flood of December 23, 1965, in the Safford Valley

19. San Francisco River flood plain at Clifton.

20. Flood of December 21, 1965, at Clifton

21. Gila River flood plain in 1935 and flood of December 23, 1965, at Little Hollywood 22. Hydrographs showing floodflows .

23. Graph showing peak-discharge frequency curves... 


\section{T A B L E S}

TABLE

1. Precipitation data for six U.S. Weather Bureau stations in or near the Gila River basin above Coolidge Dam.

2. Winter precipitation and runoff during water years 1921-30 and 1951-60

3. Mean summer streamflow at gaging stations in or near the Gila River basin, 1938-61

4. Estimated surface-water loss from the Gila River in the Safford Valley

5. Storm precipitation in November and December 1965 at five U.S. Weather Bureau stations in or near the Gila River basin above Coolidge Dam.... 


\title{
PREGIPITATION, STREAMFLOW, AND MAJOR FLOODS AT SELECTED SITES IN THE GILA RIVER DRAINAGE BASIN ABOVE COOLIDGE DAM, ARIZONA
}

\author{
By D. E. BurKhaM
}

\begin{abstract}
The Gila River Phreatophyte Project is a water-budget study to measure evapotranspiration from a 15-mile reach of the Gila River flood plain above Coolidge Dam in southeastern Arizona. Its principal purpose is to determine how much the water yield of the project area can be increased by replacing deep-rooted nonbeneficial woody plants with shallow-rooted beneficial grasses. Necessary to the study, and also for the application of the findings to other areas, is an understanding of the hydrologic variables and relations that affect the quantity of water draining toward the project area and of the environmental changes that would result from vegetation alteration. This report, which is based on available precipitation and runoff data at selected sites, is an analysis of those variables and relations.

The major conclusions reached in the study are that there has been a fluctuating decline in annual precipitation and an almost continual decline in annual runoff since 1920. The decrease in precipitation has been mainly during the winter (November through April) and has resulted in a lower incidence of major floods. For example, major floods occurred in nine winters in the period 1891-1916, but only one major flood (December 1965) occurred in the period 1917-65. No significant progressive decrease has occurred in the ratio of runoff to a given amount of precipitation since 1920 , nor has there been a progressive increase in the streamflow losses from the Gila River in Safford Valley.
\end{abstract}

\section{INTRODUCTION}

\section{PURPOSE AND SCOPE OF THIS REPORT}

This report is the result of studies that were undertaken to describe the hydrologic variables pertinent to the Gila River Phreatophyte Project; it summarizes and statistically treats the precipitation and streamflow data from selected sites in the basin above the project lands. Of particular concern is the evidence for, or for a lack of, progressive trends in the annual surface-water supply to the project lands and in streamflow losses within Safford Valley, which is upstream from those lands. Also included in the report is a description of the major historic floods in the basin.

The main purpose of the Gila River Phreatophyte Project is to determine how much the water supply would be increased through eradication of the non- beneficial deep-rooted native vegetation, mostly s.ltcedar and mesquite, and its replacement with a beneficial short-rooted plant such as Bermuda grass (Culler, 1965, p. 33-38). Necessary for the determination, and also for the application of the findings to other areas, is an understanding of the environmental factors that af ect the quantity of water draining toward the project a rea and of the environmental changes that would result from vegetation alteration.

The native vegetation increases both the resistanc? to flow and the stability of the flood-plain boundary. Therefore, replacement of the native vegetation is lilely to affect changes in the rates of erosion and deposition and to cause changes in channel width, depth, sinuosity, gradient, and even location. Concurrently, natural flowregime modifications unrelated to vegetation replacement are likely to cause changes of the same t?pe, although not necessarily in the same direction. So that the changes caused by one can be distinguished from those caused by the other, it is essential that a basis for identifying those resulting from natural flow-regime modifications be established. It is the purpose of this report to define, as nearly as possible, the natural flow regime for the period $1875-1962$. The natural flowregime modifications in the channel will be established and described in subsequent reports.

\section{ACKNOWLEDGMENTS}

This report was prepared under the general supervision of H. M. Babcock, district chief of the Water Resources Division of the U.S. Geological Surve: in Arizona, and is the result of evapotranspiration studies for the Gila River Phreatophyte Project, of which P. C. Culler is the project chief.

\section{DESCRIPTION OF THE GILA RIVER BASIN ABOVE COOLIDGE DAM}

An area of 11,500 square miles contributes runoff to the 15-mile study reach of the Gila River Phreatophyte 


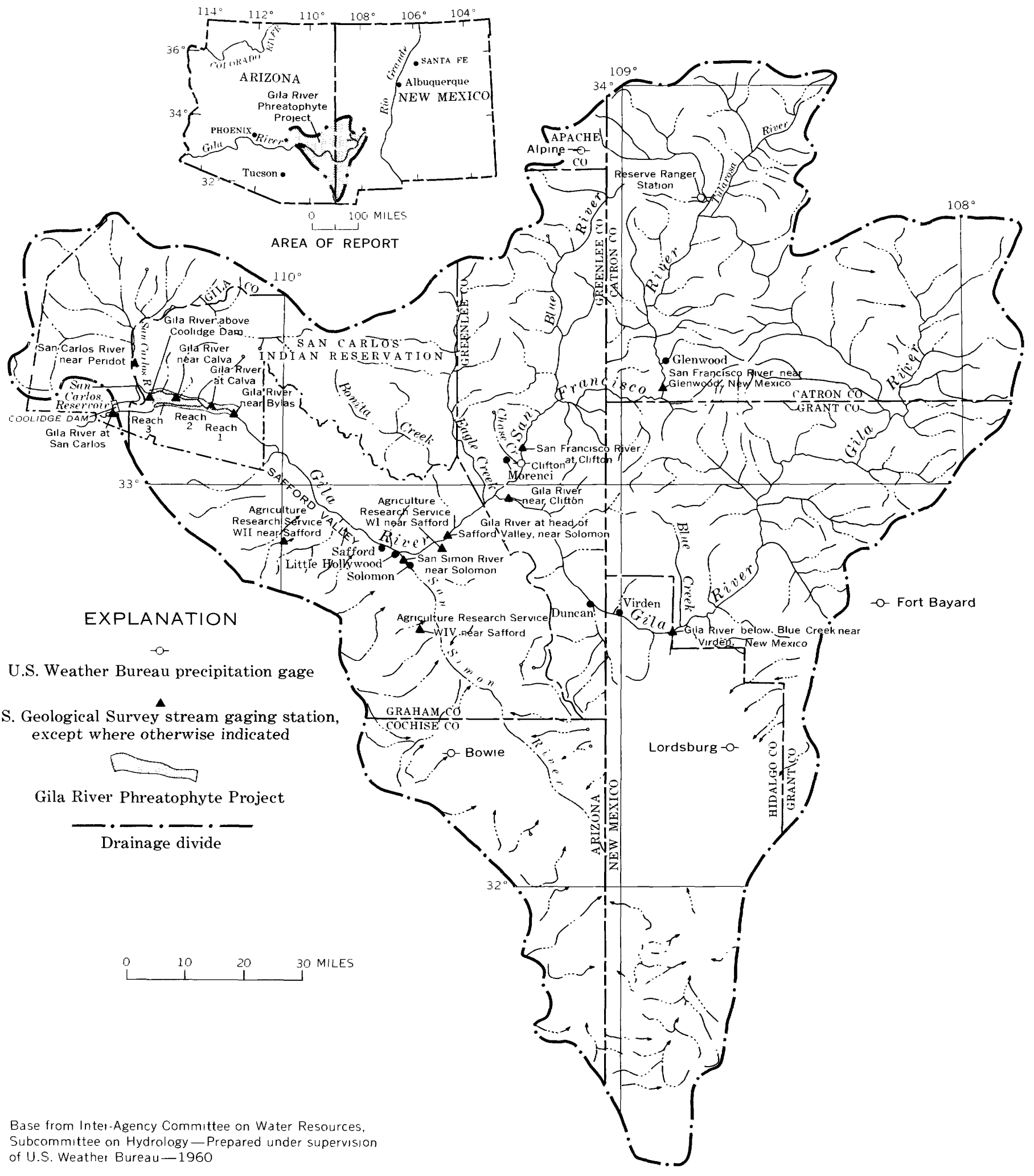

FIGURE 1.-Location of precipitation gages and stream-gaging stations. 
Project. The drainage basin ranges in altitude from 2,500 to 11,000 feet above mean sea level and extends eastward from the San Carlos Reservoir into the mountains of New Mexico (fig. 1). Topographically, it is typical of most of the basins in the Basin and Range physiographic province (Fenneman, 1931); the main valley along the Gila River is wide and flat and the mountain ranges are narrow and rugged.

Climatically, the Gila River basin is in the Sonoran Border zone (Thomas, 1962, p. 13). A wide range characterizes the temperature and the average annual precipitation. The temperature extremes recorded at Safford, which is 2,900 feet above mean sea level, are $7^{\circ}$ and $114^{\circ} \mathrm{F}$, and at Alpine, which is 8,000 feet above mean sea level, the extremes are $-29^{\circ}$ and $92^{\circ} \mathrm{F}$ (Sellers, 1960). The average annual precipitation ranges from about 8 inches in parts of the San Simon basin to more than 40 inches in the mountainous areas; the average for the entire Gila River basin above Coolidge Dam is about 14 inches.

Although the mountainous areas are mostly forested and the flood plains support a dense cover of phreatophytes, the remainder of the basin is only sparsely vegetated. In the Gila River Phreatophyte Project area, saltceder (Tamarix pentandra Pall.) is the dominant plant near the banks of the main channel, and mesquite (Prosopis juliflora var. velutine "Woot." Sarg.) is the dominant plant along the flood-plain margin. Much of the basin is used for grazing, and many small dams have been built. Most of the detention and retention dams were constructed for sediment and erosion control.

About 108 square miles (69,000 acres) of valley land is under cultivation (Barr, 1954, p. 14-17), and the principal crops are cotton and alfalfa. Part of the water for irrigation is diverted from the Gila River at several places, and the remainder is obtained from wells. At the present time (1966), there are no large surface reservoirs or any water diversions into or out of the Gila River basin above the San Carlos Reservoir.

\section{PRECIPITATION}

\section{TYPES OF AIRMASSES}

The climate of the Gila River basin is the result of five main types of airmasses. These have been identified by Thornthwaite, Sharpe, and Dosch $(1942$, p. 4) as: (1) cool moist Polar Pacific from the northern Pacific Ocean, (2) warm moist Tropical Pacific from the southern Pacific Ocean, (3) warm moist Tropical Gulf from the Gulf of Mexico, (4) cold dry Polar Continental from Canada, and (5) hot dry Tropical Continental from Mexico. The amount of moisture and the weather in general at any given time or place is influenced in many ways by these airmasses, but some types of movement are predominant in certain areas and seasons.

In the Gila River basin, Polar Pacific and Polar Continental airmasses account for most of the moisture in winter, November through April, whereas the Tropic Continental type predominates in the spring, May ard June, and the Tropical Gulf type predominates in the summer, July through October. Tropical Pacific airmasses move over the basin frequently and occasionally bring large amounts of precipitation. These airmass's are generated as a result of low-pressure areas between Hawaii and southern California, and they move east,ward across the southwestern part of the United States, usually in late summer or early winter (Thomas, 1962, p. 9).

Striking deviations of the weather from average conditions occur when a particular type of airmass brings large amounts of moisture to the basin more or less frequently than is usual. For instance, the crossing of eight Tropical Pacific storms over the Gila basin in early 1941 resulted in one of the wettest winters of record; in late 1965 the crossing of six or more Tropical Pacific airmasses over the area in rapid succession also resulted in large amounts of precipitation.

\section{STORM TYPES}

Two distinct types of storms characterize the seasonal pattern of precipitation on the Gila River basin above Coolidge Dam. Summer storms are mainly of the local convective type, and storms in the rest of the year are generally of the convergence, or frontal, type. The tro storm types result from different circumstances or "populations" of synoptic regimes.

The local convective storm, most commonly called a thunderstorm, is characterized by rainfall of high intensity and short duration in a small area. Dorroh (194.6, p. 5) stated: "Although rainfall may occur at many locations on a given day, there is little conformity in either rates or amounts that may occur at two different places, since very localized atmospheric conditions are the predominating factors involved." Because heating of the air near the ground is the main cause of convective action, thunderstorm occurrences decrease in ccld weather.

The convergence, or frontal, storm is an atmospheric disturbance of a general nature and commonly distributes much moisture over a large area. A convergerce storm may occur when airmasses of dissimilar charesteristics meet or override one another or when warm sir converges toward a center and is forced upward (Dorroh, 1946, p. 6).

Although thunderstorms occur mainly in the summer and frontal storms occur primarily in the spring 
and winter, thunderstorm activity accompanies some frontal storms. When widespread low-intensity rainfall from frontal storms is accompanied by local highintensity rainfall from convective storms, large volumes of runoff may be the result.

\section{VARIABIIITY}

Precipitation on the Gila River drainage basin above the project lands differs greatly in amount from place to place within any given season or year and at any particular location both seasonally and annually. Such variability is generally characteristic of the precipitation pattern in large inland areas having marked topographic relief and an arid climate. A large mass of precipitation data has been collected in the area by the U.S. Weather Bureau (issued annually), and it is the purpose of this section to summarize these data statistically and to determine whether any long-term trends in precipitation amounts can be identified.

Statistical analyses were made from records from the following Weather Bureau stations : Alpine, Bowie, and Clifton in Arizona and Fort Bayard, Lordsburg, and Reserve Ranger Station in New Mexico (fig. 1). These particular stations were chosen for their length of record and geographic location, and the amount and pattern of precipitation at each are assumed to be typical of similarly located sites within the drainage area above the project lands. Bowie, Clifton, and Lordsburg are in topographically low parts of the drainage area, and the other three are in mountainous areas.

In analyzing the frequency distribution of precipitation amounts at these six stations, the following statistics were computed for winter, spring, summer, and annual precipitation at each station and for the entire drainage area: the mean, the standard deviation, and the coefficient of variation. The results are presented in table 1 .
The means for the individual stations indicate the amounts that would have been received seasor ally and annually at those particular sites if the seasional and annual totals for the period of record had been evenly distributed with time; the means for the entire drainage area indicate the amounts that would have been received seasonally and annually at any site if the seasonal and annual totals for the six stations had been evenly distributed areally. As means can be distorted greatly by extreme values, they may not be wholly typical, and their usefulness for predicting quantities of rrecipitation to be expected in future periods of time is limited. They are useful, however, for making comparisons of amounts of precipitation in different seasons at the same site and the amounts received seasonally and annually at the different stations. The mean annual precipitation at the individual stations ranged from 9.64 to 20.48 inches, and for all stations was 13.77 inches. $O^{e}$ this last amount, 36 percent occurred in winter, 7 percent in spring, and 57 percent in summer. The mean precipitation for all seasons is typically greater in the mountains than in the valleys.

The standard deviation is sometimes refermed to as the root-mean-square deviation because it is th square root of the mean of the squares of the individual deviations. It is of limited value when used in a nonnormal frequency distribution such as precipitation because the larger deviations are overemphasized in the process of squaring the deviations. Its value is limited further because, for example, a standard deviation of 1 inch of precipitation in a humid climate would have very little meaning, but in an arid region it may be highly significant. The standard deviation for the precipitat on at the individual stations ranged from 2.02 to 2.90 inches in the winter, 2.06 to 3.72 inches in the summer, and 0.44 to 0.89 inch in the spring. The standard deviation for annual precipitation at the individual stations ranged from 3.37 to 4.83 inches.

TABLE 1.-Precipitation data for six U.S. Weather Bureau stations in or near the Gila River basin above Coolidge Dam

\begin{tabular}{|c|c|c|c|c|c|c|c|c|c|c|c|c|c|c|c|c|c|c|c|c|c|c|}
\hline \multirow{3}{*}{ Station } & \multirow{3}{*}{$\begin{array}{c}\text { Alti- } \\
\text { tude } \\
\text { (feet } \\
\text { above } \\
\text { mean } \\
\text { sea } \\
\text { level) }\end{array}$} & \multirow{3}{*}{$\begin{array}{l}\text { Period } \\
\text { of } \\
\text { record }\end{array}$} & \multicolumn{4}{|c|}{ Mean (inches) } & \multicolumn{4}{|c|}{$\begin{array}{l}\text { Standard deviation } \\
\text { (inches) }\end{array}$} & \multicolumn{4}{|c|}{ Coefficient of variation } & \multicolumn{8}{|c|}{ Extremes (inches) } \\
\hline & & & \multirow[b]{2}{*}{ 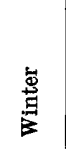 } & \multirow[b]{2}{*}{ 皆 } & \multirow[b]{2}{*}{ 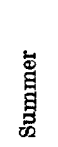 } & \multirow[b]{2}{*}{ 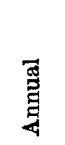 } & \multirow[b]{2}{*}{ 蒂 } & \multirow[b]{2}{*}{ 葶 } & \multirow[b]{2}{*}{ 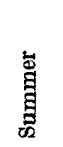 } & \multirow[b]{2}{*}{ 䎡 } & \multirow[b]{2}{*}{ 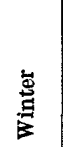 } & \multirow[b]{2}{*}{ 唃 } & \multirow[b]{2}{*}{ 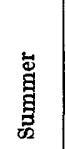 } & \multirow[b]{2}{*}{ 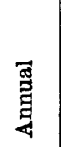 } & \multicolumn{2}{|c|}{ Winter } & \multicolumn{2}{|c|}{ Spring } & \multicolumn{2}{|c|}{ Summer } & \multicolumn{2}{|c|}{ Annual } \\
\hline & & & & & & & & & & & & & & & 离紊畐 & 䓌景 & 离泀 & 党是 & 密园 & 竞园 & 离星 & 官鼻 \\
\hline \multirow{6}{*}{$\begin{array}{l}\text { Arizona: } \\
\text { Alpine.... } \\
\text { Bowie } \\
\text { Clifton } \\
\text { New Mexico: } \\
\text { Fort Bayard.... } \\
\text { Lordsburg } \\
\text { Reserve Ranger } \\
\text { Station }\end{array}$} & & & & & & & & & & & & & & & & & & & & & & \\
\hline & 8,000 & $1912-1965$ & 7.42 & 1.44 & 11.61 & 20.48 & 2. 50 & 0.86 & 2. 91 & 4.13 & 0.34 & 0.60 & 0.25 & 0.20 & 14.24 & 3.03 & 3. 77 & 0.10 & 20.00 & 6. 31 & 33.48 & 12. 02 \\
\hline & $\begin{array}{l}3,756 \\
\mathbf{3}, 465\end{array}$ & $\begin{array}{l}1899-1965 \\
1893-1965\end{array}$ & $\begin{array}{l}3.82 \\
4.83\end{array}$ & $\begin{array}{l}.46 \\
.73\end{array}$ & $\begin{array}{l}5.86 \\
7.15\end{array}$ & $\begin{array}{l}10.14 \\
12.71\end{array}$ & $\begin{array}{l}2.02 \\
2.90\end{array}$ & $\begin{array}{r}.44 \\
71\end{array}$ & $\begin{array}{l}2.06 \\
2.27\end{array}$ & $\begin{array}{l}3.43 \\
3.90\end{array}$ & $\begin{array}{r}.53 \\
60\end{array}$ & $\begin{array}{r}.98 \\
96\end{array}$ & .35 & .34 & 10.01 & $\begin{array}{r}.35 \\
1.25\end{array}$ & 1.94 & $\begin{array}{l}0 \\
0\end{array}$ & $\begin{array}{l}11.37 \\
13.99\end{array}$ & $\begin{array}{l}1.44 \\
1.98\end{array}$ & $\begin{array}{l}17.71 \\
26,71\end{array}$ & $\begin{array}{l}\text { 3. } 07 \\
\text { 6. } 18\end{array}$ \\
\hline & & & & & & & & & & & & & & & & & & & & & & \\
\hline & $\begin{array}{l}6,152 \\
4,245\end{array}$ & $\begin{array}{l}1867-1962 \\
1881-1962\end{array}$ & $\begin{array}{l}\text { 4. } 59 \\
\text { 3. } 49\end{array}$ & $\begin{array}{r}1.12 \\
.57\end{array}$ & $\begin{array}{l}9.62 \\
5.58\end{array}$ & $\begin{array}{r}15.33 \\
9.64\end{array}$ & $\begin{array}{l}2.68 \\
2.09\end{array}$ & $\begin{array}{l}.89 \\
.60\end{array}$ & $\begin{array}{l}\text { 3. } 72 \\
2.49\end{array}$ & $\begin{array}{l}4.83 \\
3.49\end{array}$ & $\begin{array}{l}.58 \\
.59\end{array}$ & $\begin{array}{r}.80 \\
1.05\end{array}$ & $\begin{array}{l}.39 \\
.45\end{array}$ & $\begin{array}{l}.31 \\
.36\end{array}$ & $\begin{array}{l}17.03 \\
11.19\end{array}$ & $\begin{array}{l}.57 \\
.20\end{array}$ & $\begin{array}{l}3.74 \\
2.25\end{array}$ & $\begin{array}{l}0 \\
0\end{array}$ & $\begin{array}{l}17.17 \\
12.77\end{array}$ & $\begin{array}{r}3.13 \\
.99\end{array}$ & $\mid \begin{array}{l}30.64 \\
19.78\end{array}$ & $\begin{array}{l}4.89 \\
\text { 3. } 96\end{array}$ \\
\hline & 5,832 & 1917-1962 & 5.64 & 1.09 & 7.65 & 14.37 & 2.15 & .79 & 2.14 & 3.37 & .38 & .73 & .28 & .23 & 12.22 & 2.25 & 3. 24 & 0 & 12.20 & 3. 63 & 25.56 & 8.54 \\
\hline Avg. & & & 4.96 & 0.90 & 7.91 & 13. 77 & & & & & & & & & & & & & & & & \\
\hline
\end{tabular}


The coefficient of variation is the ratio of the standard deviation to the mean. It is a more useful statistic than the standard deviation because it is a relative rather than an absolute statistic. The surprising fact is that the coefficient of variation for winter precipitation for all stations is larger than that for summer. This is probably due to the Tropical Pacific storms, which occasionally produce large amounts of precipitation in the Southwest, as they did in 1941. The coefficient of variation of winter precipitation is larger than that of summer precipitation, but this is true only in a temporal sense. According to McDonald (1956, p. 64), the spatial variability of summer precipitation is greater than that of winter precipitation.

McDonald (1956, p. 9) stated that the circulation factors governing the relative amounts of cyclonic winter precipitation in Arizona are more variable from year to year than the large-scale factors governing the arrival of summer moisture and its precipitation. However, all Arizona shows a tendency to be concurrently either generally wet or dry in the winter but shows no such tendency in the summer.

Graphs of the 10-year progressive average precipitation at the six stations are shown in figure 2. These for summer precipitation show short periods of relatively low and relatively high precipitation but no long-term trends in either direction. For example, the 10 -year average summer precipitation trended downward during the decade ending in 1956 and then trendod upward through 1962 . On the other hand, winter precipitation trended generally downward from 1920 through 1962. The reason for the downward trend in winter precipitation is not known, but, according to McDonald $(1956$, p. 24), the general circulation of the
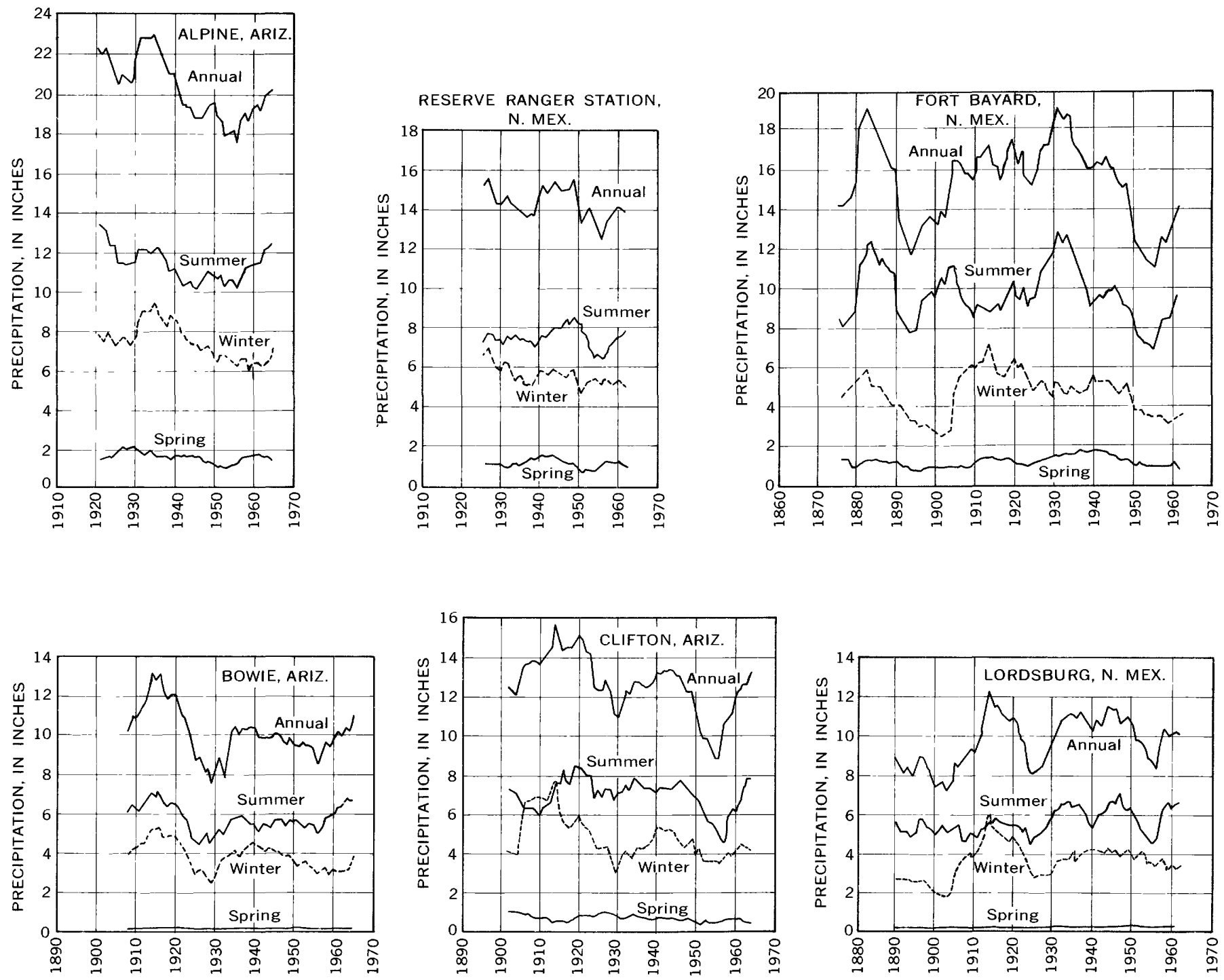

Figure 2.-Progressive 10-year average of seasonal precipitation at six stations in or near the Gila River basin. Lach 10-year average is plotted above the year that ends the decade.

$368-7500-70 \longrightarrow 2$ 
airmasses has, in some way, been responsible for the fluctuating decline in winter precipitation. As the amount of precipitation in the spring is very small, trends in spring precipitation have only minor hydrologic significance.

\section{STREAMFLOW}

\section{SEASONAT TYPES}

Streamflow is classified as winter flow and as summer flow. Winter flow is the result of precipitation that falls from November through April, and summer flow is the result of precipitation that falls from July through October. The small amounts of precipitation in May and June seldom, if ever, result in any direct runoff.

Winter flow is mainly from frontal storms, snowmelt, or outflow from ground-water storage and often is a combination of the three. The flow rate may be fairly constant for several days (fig. 3). The causes of major winter floods are widespread heavy rainfall of long duration, warm weather after a large snow accumulation, or widespread rainfall on snow.

Local thunderstorms are the main source of summer streamflow. Individual summer thunderstorms characteristically produce high unit rates and volumes of flow from small watersheds, but only rarely do they produce high rates or volumes of flow from large watersheds. The crest of a flood from a thunderstorm is typically very sharp near the source of the surface flow but may become rounded or flattened downstream because of the regulating effects of the conveyance system. Sometimes, when the runoff from a thunderstorm enters a dry stretch of channel, the flood crest disappears completely because all the flow sinks into the underlying alluvium. The summer flow of the Gila River through the Gila River Phreatophyte Project area is the composite runoff that results from thunderstorms at several localities. A typical hydrograph shows that the flow varies greatly in a short period of time (fig. 4).

During the last part of September and in October, occasional frontal activity causes precipitation that produces widespread runoff. The combined runoff from

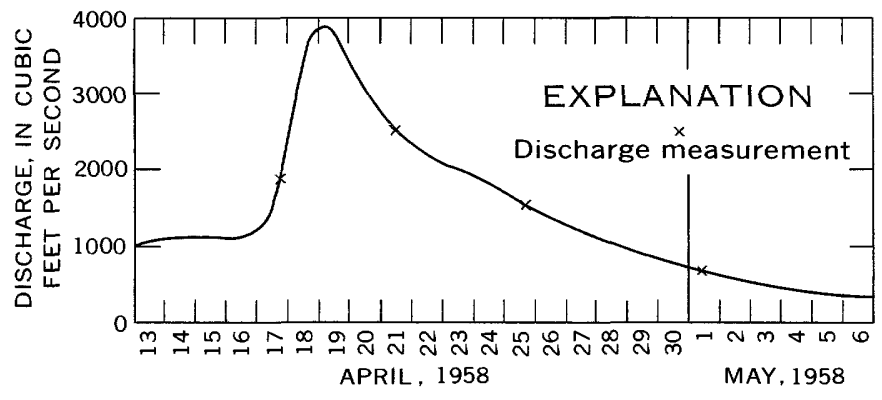

Figure 3.-Winter flow, Gila River at Calva. general rains and concurrent local thunderstorms often results in the major flows of the summer season.

\section{BASIC DATA}

Streamflow records from seven U.S. Geological Survey gaging stations in the Arizona part of the Gila River basin were used in this study. Listed in a downstream order, the stations are (1) Gila River near Clifton, (2) San Francisco River at Clifton, (3) Gila Fiver at head of Safford Valley, near Solomon, (4) San Simon River near Solomon, (5) Gila River at Calva, (6) San Carlos River near Peridot, and (7) Gila River at San Carlos (fig. 1).

The drainage area of 4,010 square miles above the gage on the Gila River near Clifton is about 50 percent mountainous terrain. The 43-year (1911-17 and 192764) surface-water yield was 32.9 acre-feet per square mile per year (U.S. Geological Survey). At the present time (1966), surface water is diverted for the irrigation of about 14,300 acres above the station.

The drainage area of 2,766 square miles above the gage on the San Francisco River at Clifton is mostly mountainous. The 40-year (1913-15, 1916-17, and 192764) surface-water yield for the period of record was 47.1 acre-feet per square mile per year. Most of the major floods of the Gila River at San Carlos originate in the mountains near Clifton. At the present time (1966), surface water is diverted for mining, municipal use, and the irrigation of about 2,700 acres above the station.

The flow at the Gila River at head of Safford Valley gaging station is essentially the sum of the flows past the San Francisco River at Clifton and the Gila River near Clifton gaging stations. Discharge from Eagle Creek and other small tributaries contributes to the flow. Eagle Creek and the other small tributaries have drainage basins that total about 1,120 square miles.

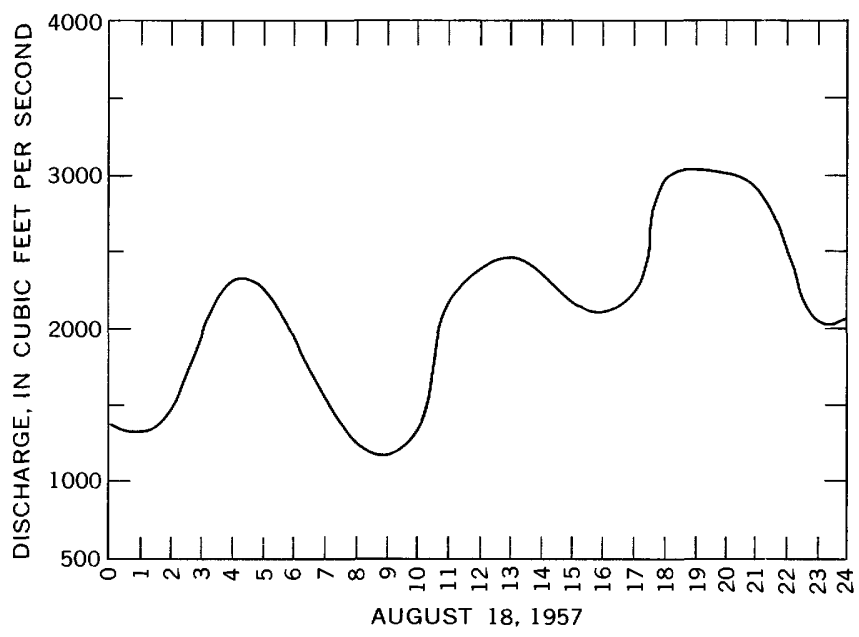

Figure 4.-Summer flow, Gila River at Calva. 
The drainage area of the 2,192-square-mile San Simon basin is mostly nonmountainous terrain. The surface flow from the San Simon basin is partly regulated by conservation reservoirs. The 30-year (1931-32, 1935-64) surface-water yield was 5 acre-feet per square mile per year (U.S. Geological Survey). At the present time (1966), about 13,800 acres of the basin is under irrigation. Most of the water for irrigation is obtained from wells.

The gaging station on the Gila River at Calva is in the Gila River Phreatophyte Project area; the basin above the station is described in the "Introduction." The 35-year (1929-64) surface-water yield was 15.2 acrefeet per square mile per year (U.S. Geological Survey).

The drainage area of the 1,027-square-mile basin upstream from the gage on the San Carlos River near Peridot is mostly mountainous. The 35-year (1929-64) surface-water yield was 31.4 acre-feet per square mile per year. At the present time (1966), about 600 acres is under irrigation above the station.

The data for the Gila River at San Carlos were recorded at the station "Gila River at" or "near" San Carlos prior to the completion of Coolidge Dam in 1927; subsequent to 1927 the record is the composite data from two stations, Gila River near Calva and San Carlos River near Peridot. Ungaged tributaries having a composite area of 389 square miles exist between the two systems of gaging stations. In this report, the sum of the seasonal or annual flow in the Gila River at Calva plus the seasonal or annual flow in the San Carlos River near Peridot are assumed to be equivalent to the seasonal or annual flow in the Gila River at San Carlos. In describing the sum of flows in the two rivers, the phrase "flow in the Gila River at San Carlos" is used unless otherwise noted.

\section{FREQUENCY AND VARIABILITY OF DAIIY AND SEASONAL GILA RIVER FLOW THROUGH SAFFORD VALLEY}

The following discussion is based on data from two gaging stations-Gila River at head of Safford Valley and Gila River at Calva. The record at Calva was used because an analysis of the frequency of occurrence of seasonal flow was available from a study of errors in streamflow data (Burkham and Dawdy, 1970). The data for the Gila River at head of Safford Valley were used because the station has the longest contimuous record of any station in the Gila River basin. The "head of Safford Valley" gage is about 55 miles upstream from the Gila River Phreatophyte Project. The variability and range in flows at the two stations are typical of mainstem flows.

The average summer flow for 1914-64 past the head of
Safford Valley gage was about 97,300 acre-feet, or 32 percent of the annual average discharge. The extremes in summer flow were about 15,700 acre-feet in 1956 and 345,000 acre-feet in 1916; the standard deviation was 71,300 acre-feet, and the coefficient of variation was 0.71 . The lowest average summer discharge for 10 years (1943-53) was about 44,800 acre-feet, and the higl ast (1914-24) was 164,000 acre-feet.

The characteristics of summer flow are summarized by flow-duration curves (fig. 5), which show the frequency distribution of the average daily flow past the "head of Safford Valley" gage and the "at Calva" gage for 1930-40 and 1951-61. The two periods represent wet and dry periods, respectively. The steep slopes of the duration curves, which denote a large variability in flow past the Calva gage, are characteristic of the ephemeral streams of the Southwest. The median flowflow that is equaled or exceeded about 50 percent of the time-past the Calva gage was 45 efs (cubic feet per second) for 1930-40 but only 5 cfs for 1951-61. The median flow at the head of Safford Valley was $175 \mathrm{cfs}$ and $95 \mathrm{cfs}$ for the wet and dry periods, respectivaly. The flow that was equaled or exceeded about 10 percent of the time had about the same frequency of occurrence during the two periods.

The average winter flow at the head of Safford Valley gage for 1914-64 was about 210,000 acre-feet, or 68 percent of the average annual discharge. The least winter flow was about 19,600 acre-feet in 1959, and the greatest was about 1,180,000 acre-feet in 1916; the standard deviation was 220,000 acre-feet, and the coefficient of variation was 1.04 . The highest average winter discherge for 10 years (1914-24) was about 377,000 acre-feet, and the lowest (1949-59) was about 105,000 acre-feetabout a 270 percent difference in 10 -year averages.

The characteristics of winter flow are summarized by flow-duration curves (fig. 6), which show the frequency distribution of the average daily flow past the head of Safford Valley gage and the Calva gage for $1930-10$ and 1951-61. The median flow past the Calva gage was 120 cfs for 1930-40 and $25 \mathrm{cfs}$ for 1951-61; at the head of Safford Valley the median flow was $120 \mathrm{cfs}$ and $80 \mathrm{cfs}$ for the same time periods.

The average annual flow for 1914-64 past the lad of Safford Valley gage was about 316,000 acre-feet. The low of 49,100 acre-feet (1956) is about 15.6 percent of average, and the high of about 1,600,000 acre-feet (1915) is about 510 percent of average. The average flow was exceeded only four times in the 22-year period $1942-64$ and six times in the 31-year period $193 \hat{\varepsilon}-64$. The standard deviation of the annual flow for the 50 . year period 1914-64 is 250,000 acre-feet, and the coefficient of variation is 0.79 . The wide range in annual flow 


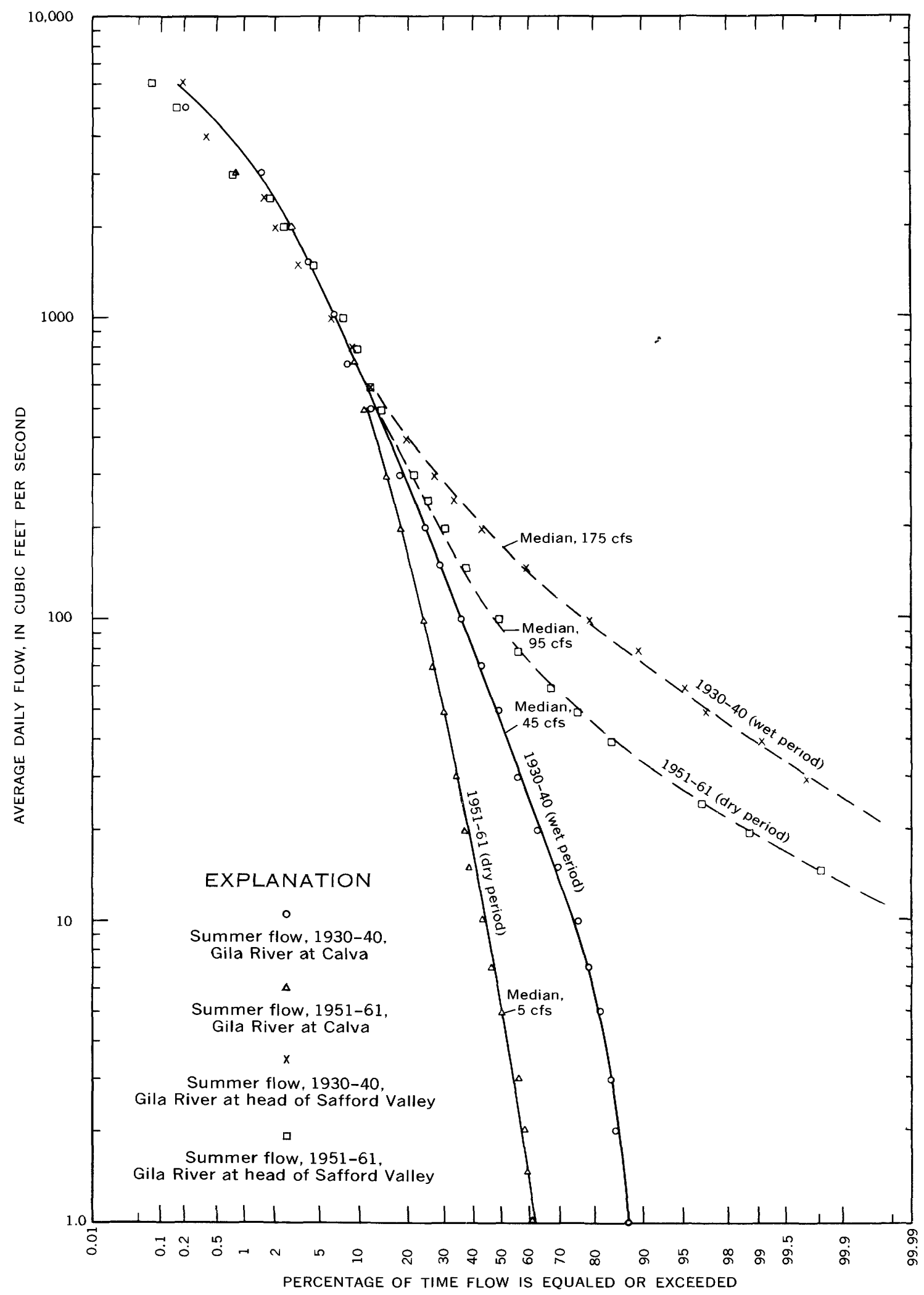

FIgURE 5.-Duration curves of summer flow, Gila River at head of Safford Valley, near Solomon, Ariz., and Gila River at Calva, Ariz. 
PRECIPITATION, STREAMFLOW, FLOODS, GILA RIVER DRAINAGE BASIN, ARIZONA

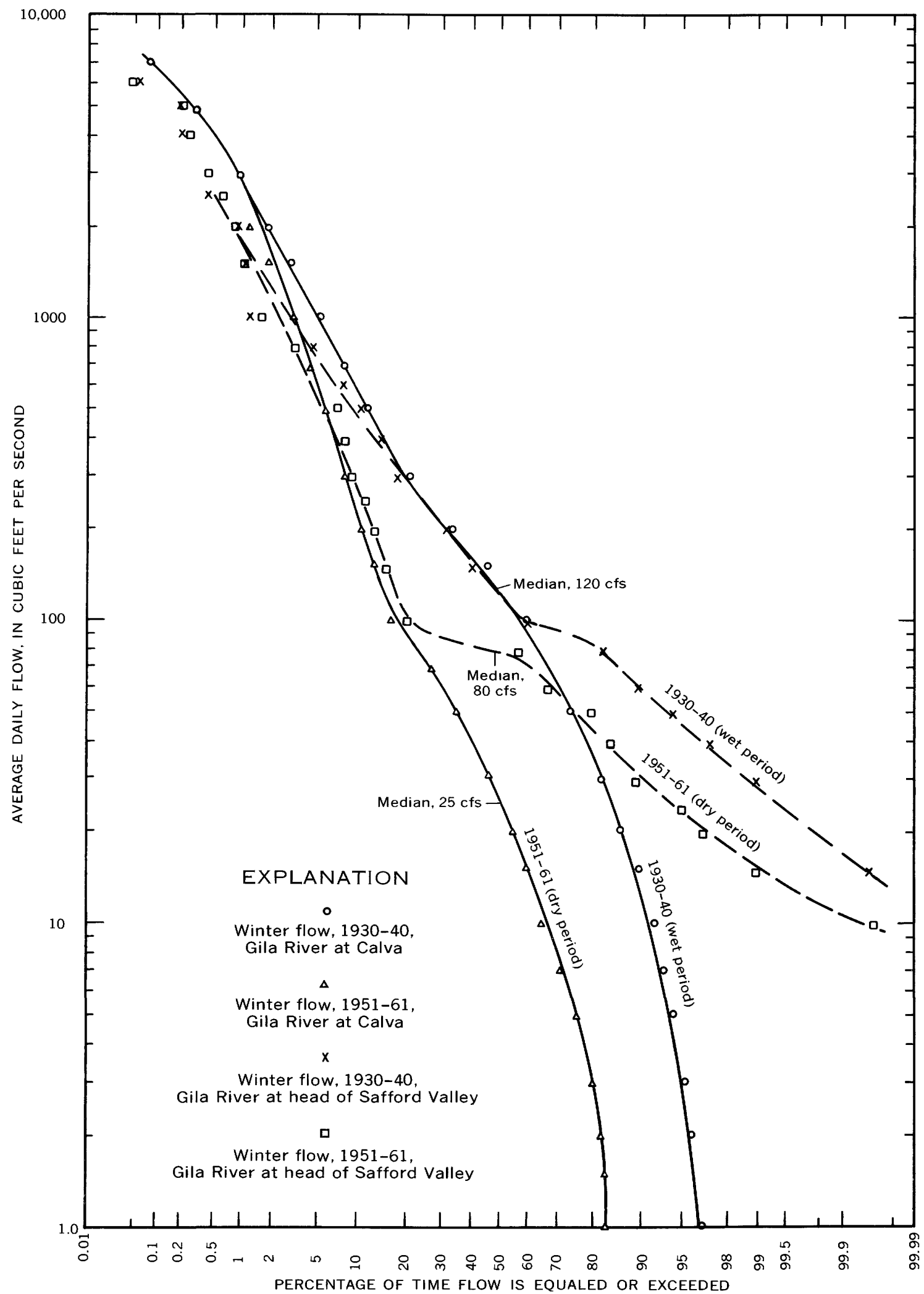

FIGURE 6.-Duration curves of winter flow, Gila River at head of Safford Valley, near Solomon, Ariz., and Gila River at Calva, Ariz. 
and the high coefficient of variation are considered normal for the station during this period.

The coefficients of variation of runoff are higher than the coefficients of variation of precipitation because runoff represents the rather small difference between the highly variable precipitation and a somewhat independent and highly variable evapotranspiration. Significantly, the coefficients of variation for both precipitation and runoff in winter are greater than those for precipitation and runoff in summer. Moreover, the range between high and low average flows is greater for winter than for summer. Thus, although thunderstorms produce short-duration small-volume flashfloods in an erratic fashion, the probability of the average seasonal flow occurring in any given year is greater in the summer than in the winter.

\section{LONG-TERM TRENDS}

A fluctuating decline in runoff for 1920-62 (fig. 7) has paralleled the general downward trend in winter precipitation. In order to illustrate the trend satisfactorily, the period of record for the Gila River at San Carlos was extended by using estimates of flow made by the U.S. Army Corps of Engineers (written commun., 1945) and Olmstead (1919, p. 19). The 1945 estimates of the Corps of Engineers are based on measured discharge at upstream points and (or) precipitation-runoff relations. The discharge data used in the relations are for different upstream sites and different time periods. No streamflow data are available for any upstream sites prior to 1905 , and only a few continuous discharge records are available prior to 1915 .

The Corps of Engineers (written commun., 1945) made a comparison of gaged flows for 1914-40 at the Coolidge damsite with computed flows for the same period from their runoff-rainfall relations. The mean of the computed summer discharge was 10.4 percent less than the mean of measured flow, and the mean of the estimated winter discharge was 1.2 percent less. The maximum difference between the gaged annual flow and the estimated annual flow for a single season was 192 percent of the measured flow.

The discharge estimates made by Olmstead (1919) are lower than those made later by the Corps of Engineers (written commun., 1945). Although the basis of Olmstead's (1919) estimate is unknown, it is significant that both estimates indicate greater flow prior to 1920 than since.

\section{PRECIPITATION-RUNOFF RELATIONS}

Studies were made to determine if the decline in annual runoff since 1920 was caused by a reduction in the ratio of runoff to precipitation. So that large changes in long-term trends could be identified, double-mass techniques and simple statistical methods were a pplied. The data from the six precipitation stations and the discharge data from the Gila River at head of Safford Valley were used in the double-mass relations.

Ordinarily, if a series of wet years is followad by a series of dry years (or vice versa), a significant change will be indicated in the long-term relation of runoff to precipitation. However, because the runoff-precipitation relation generally is curvilinear, direct comparisons of runoff to precipitation in a double-mass relatior can be misleading. In order to eliminate the effects of the curvilinear relation, the method of Oltman and Tracy (1951, p. 20-21) was used in this study of seasonal runoff to seasonal precipitation. Summarized briffly, the method is: (1) prepare a curve showing the average relation between seasonal streamflow and the corrssponding average seasonal precipitation, and (2) study the consistency of the synthetic or computed runoff from the curve and the measured runoff by use of the doublemass relation.

The relation of winter runoff at Gila River at head of Safford Valley to the average winter precipitation at the six stations for 1916-62 is shown in figure 8. The line through the plotted points yields the relation: winter runoff $=0.013$ (measured winter precipitation) ${ }^{2.1}$. The index of correlation is 0.96 , determined graphically, and the standard error of estimate is $0.10 \mathrm{log}$ unit. The double-mass relation of computed rinoff to measured runoff is shown in figure 9 ; no change or trend toward reduced winter runoff for the same precipitation for 1920-62 is apparent.

In order to place some confidence limits on the reality of no apparent change in the relation of runofl to precipitation, two simple statistical tests-the rariance ratio or $F$ test and the two-sided Student's $t$ testwere applied to the streamflow data obtained at the head of Safford Valley. The streamflow data for two 10-year periods (1920-30 and 1950-60) in which the precipitation means and deviations from the means were about the same (table 2) were used in the tests. The null hypothesis is that the two samples are from the same population.

The two-sided Student's $t$ test shows that th? runoff means for the two periods are not significantly different at the 5-percent or 1-percent levels. The variance ratio test was applied to check the homogeneity of the variances, and the difference between the variances was not significant at the 5-percent level.

The results of the tests indicate that any cl ange or trend, if one occurred, toward reduced winte" runoff for 1920-62 for the same amount of precipitatior was too 


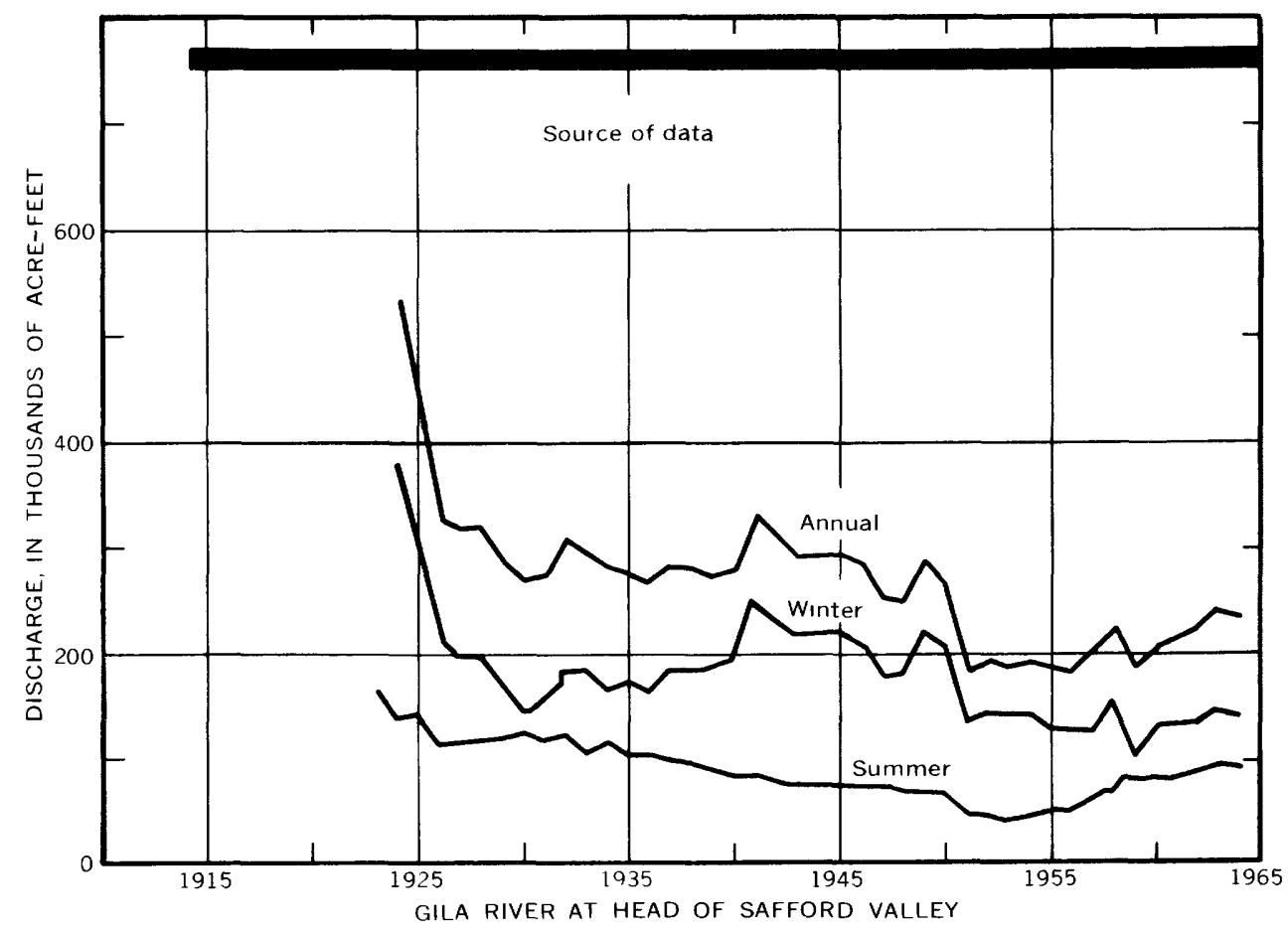

EXPLANATION

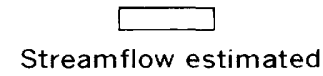

$x \times x$

Streamflow partly estimated

Streamflow gaged

$\mathrm{HH}+\mathrm{HHH}+\mathrm{HHHH+H}$

Estimate by U.S. Army Corps cf Engineers (written commun., 194.5)

Estimate by Olmstead (1919)

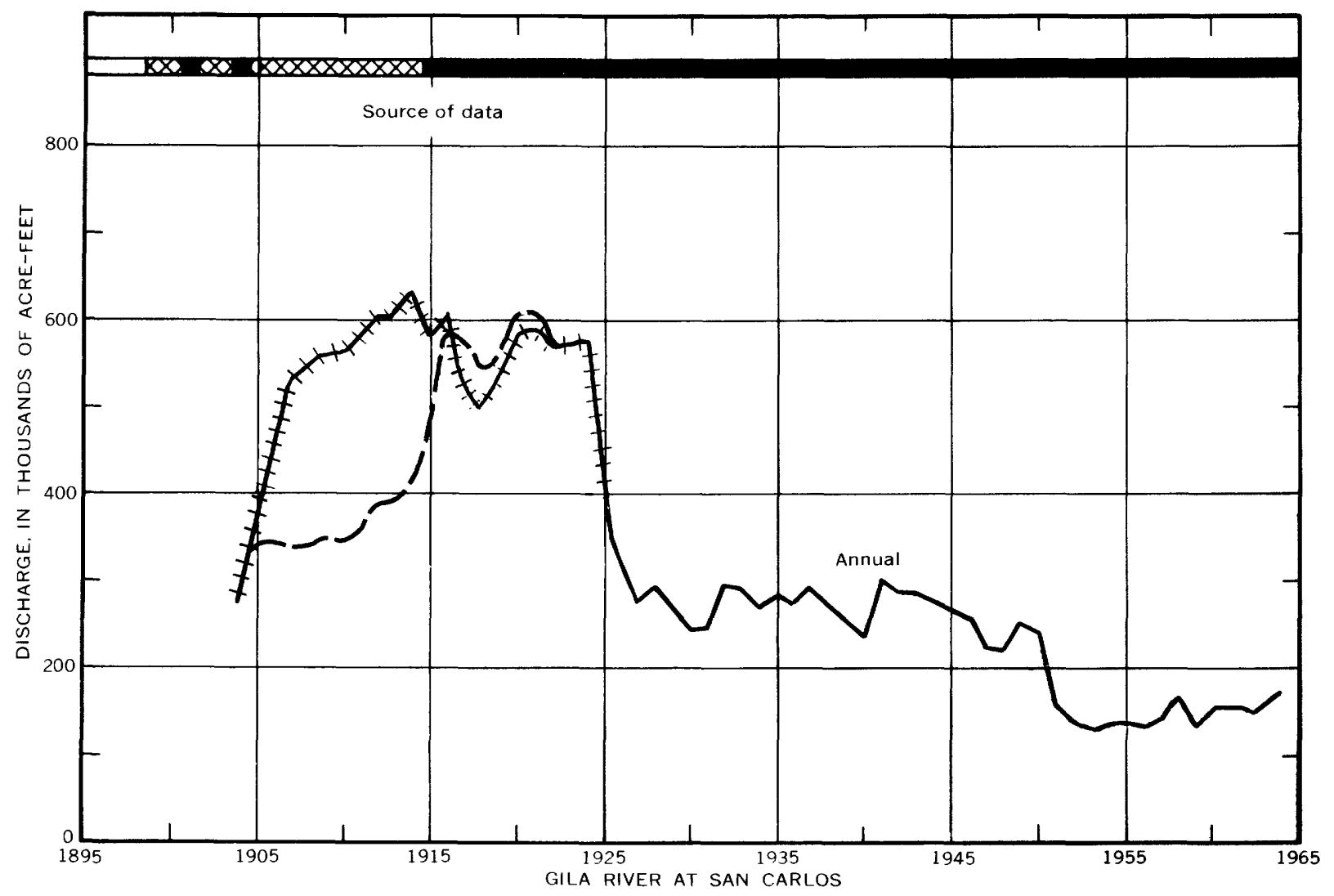

Figure 7.--Progressive 10-year average annual flow, Gila River at head of Safford Valley, near Solomon, Ariz., and Gila Rirer at San Carlos, Ariz. Prior to completion of Coolidge Dam in 1927, the Gila River flow at San Carlos was measured at one station "Gila River at San Carlos." Subsequent to 1927, the record is the composite from two stations, Gila River near Calva and San Carlos River near Peridot. Each 10-year average is plotted above the year that ends the decade. 


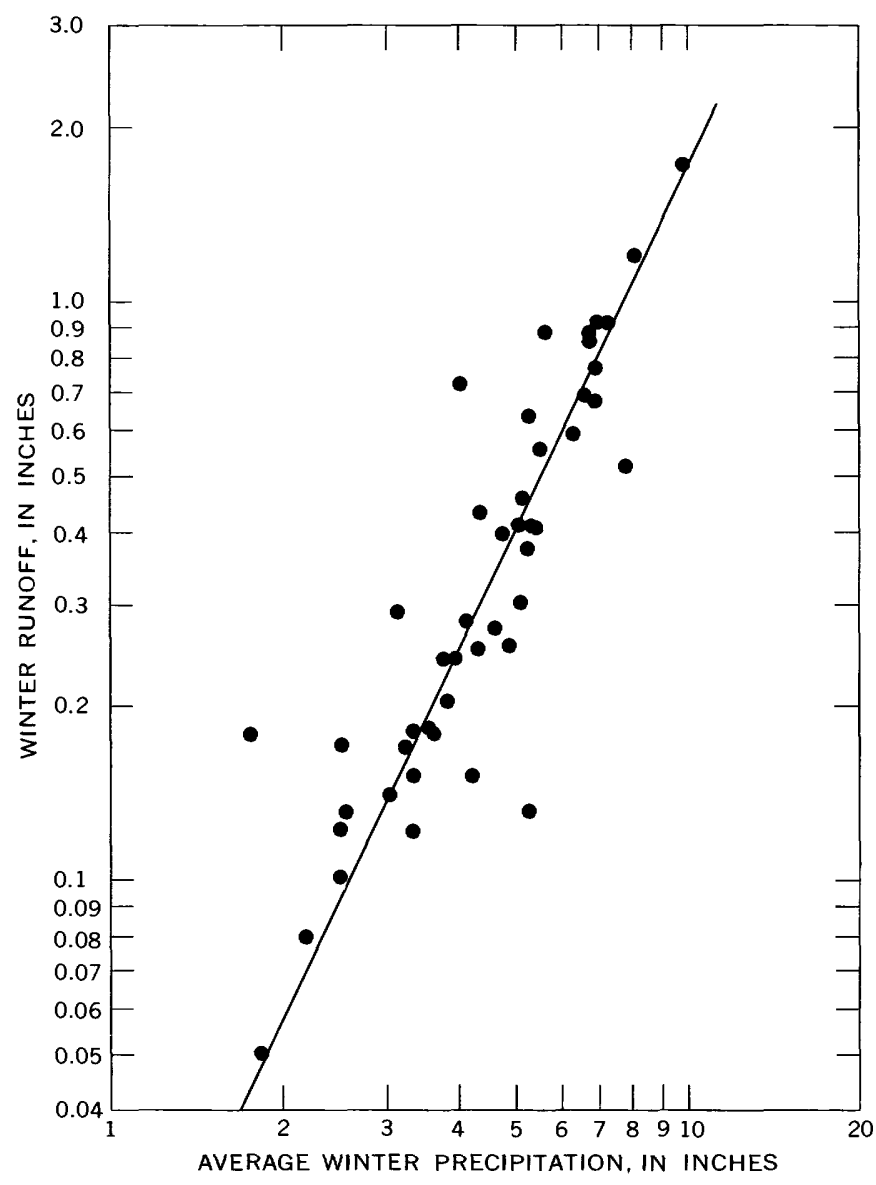

FrguRe 8.-Relation of winter runoff, Gila River at head of Safford Valley, near Solomon, Ariz., and average winter precipitation.

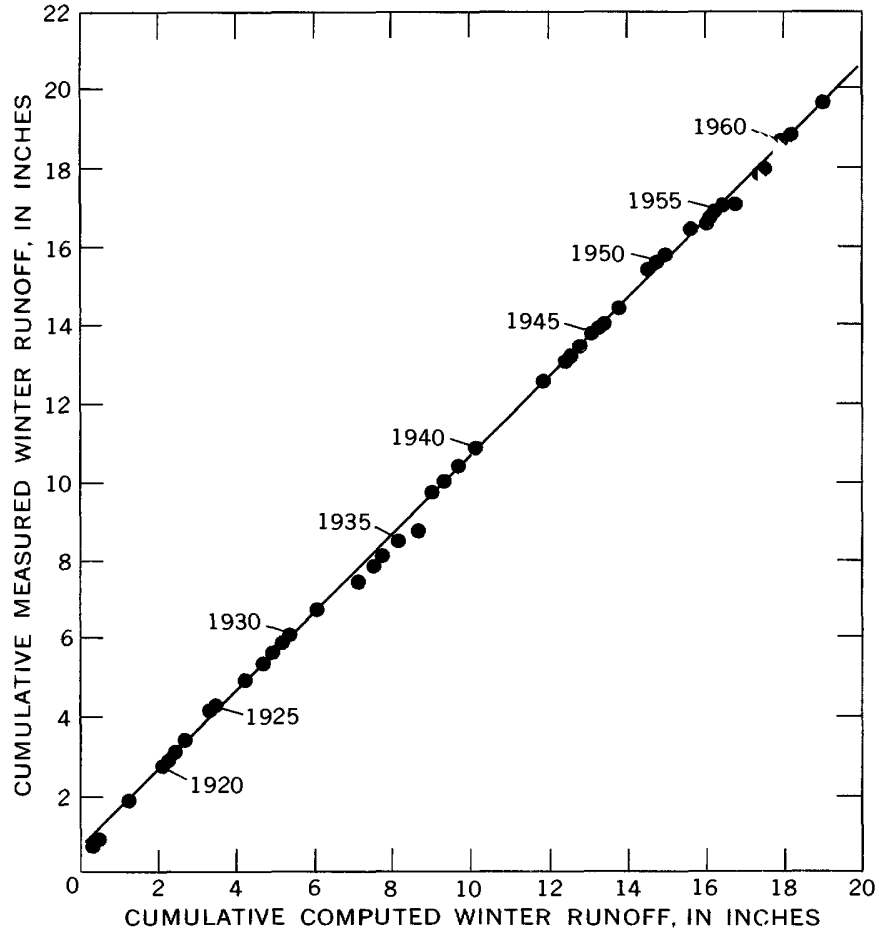

Frgure 9.-Double-mass relation of measured winter runoff versus computed winter runoff, Gila River at head $o^{\circ}$. Safford Valley, near Solomon, Ariz. Computed winter runoff $=0.013$ (measured winter precipitation) ${ }^{2.1}$.

TABLE 2.-Winter precipitation and runoff, in inches, during water years 1921-30 and 1951-60

\begin{tabular}{|c|c|c|c|c|c|c|c|c|c|c|c|c|c|c|c|c|c|c|c|c|c|c|}
\hline \multirow{2}{*}{ Station } & \multicolumn{22}{|c|}{ Water year } \\
\hline & 1921 & 1922 & 1923 & 1924 & 1925 & 1926 & 1927 & 19281 & 1929 & 1930 & $\begin{array}{l}\text { 1921-30 } \\
\text { average }\end{array}$ & 1951 & 1952 & 1953 & 1954 & 1955 & 1956 & 1957 & 19581 & 1959 & 1993 & $\begin{array}{l}1951-60 \\
\text { average }\end{array}$ \\
\hline \multicolumn{23}{|c|}{ Precipitation } \\
\hline $\begin{array}{l}\text { Arizona: } \\
\text { Alpine } \\
\text { Bowie-_. } \\
\text { Clifton }\end{array}$ & $\begin{array}{r}3.03 \\
-1.24 \\
-\quad .71\end{array}$ & $\begin{array}{l}\mathbf{5 . 3 7} \\
\mathbf{2 . 0 5} \\
\mathbf{2 . 3 4}\end{array}$ & $\begin{array}{l}7.84 \\
1.30 \\
1.70\end{array}$ & $\begin{array}{l}8.20 \\
3.04 \\
7.20\end{array}$ & $\begin{array}{r}6.07 \\
.35 \\
1.25\end{array}$ & $\begin{array}{l}9.69 \\
7.16 \\
6.04\end{array}$ & $\begin{array}{l}8.92 \\
2.92 \\
\text { 3. } 88\end{array}$ & $\begin{array}{l}8.63 \\
2.58 \\
2.62\end{array}$ & $\begin{array}{l}8.06 \\
1.05 \\
2.04\end{array}$ & $\begin{array}{l}6.96 \\
4.97 \\
1.98\end{array}$ & $\begin{array}{l}7.28 \\
2.67 \\
2.98\end{array}$ & $\begin{array}{l}3.75 \\
3.43 \\
2.32\end{array}$ & $\begin{array}{r}10.97 \\
4.66 \\
6.19\end{array}$ & $\begin{array}{l}6.52 \\
4.42 \\
6.50\end{array}$ & $\begin{array}{l}6.00 \\
2.28 \\
3.33\end{array}$ & $\begin{array}{l}3.88 \\
1.38 \\
2.05\end{array}$ & $\begin{array}{l}4.35 \\
1.39 \\
1.98\end{array}$ & $\begin{array}{l}6.32 \\
2.67 \\
3.83\end{array}$ & $\begin{array}{l}8.50 \\
5.02 \\
6.65\end{array}$ & $\begin{array}{l}3.24 \\
1.27 \\
1.45\end{array}$ & $\begin{array}{l}7.06 \\
3.67 \\
6.10\end{array}$ & $\begin{array}{l}6.06 \\
3.02 \\
4.04\end{array}$ \\
\hline $\begin{array}{l}\text { New Mexico: } \\
\quad \text { Fort Bayard. } \\
\text { Lordsburg.... } \\
\text { Reserve Ranger Station. }\end{array}$ & $\begin{array}{r}2.07 \\
.96 \\
2.63\end{array}$ & $\begin{array}{l}4.25 \\
3.51 \\
5.39\end{array}$ & $\begin{array}{l}5.99 \\
2.35 \\
6.99\end{array}$ & $\begin{array}{l}6.12 \\
4.27 \\
8.84\end{array}$ & $\begin{array}{l}1.81 \\
4.93 \\
4.71\end{array}$ & $\begin{array}{l}5.58 \\
5.28 \\
7.55\end{array}$ & $\begin{array}{l}5.83 \\
2.90 \\
\text { 5. } 98\end{array}$ & $\begin{array}{ll}5.29 & 2 \\
1.97 & 2 \\
6.72 & 3 \\
\end{array}$ & $\begin{array}{l}2.41 \\
2.07 \\
3.82 \\
\end{array}$ & $\begin{array}{l}\text { 3. } 73 \\
3.37 \\
3.83\end{array}$ & $\begin{array}{l}4.31 \\
2.72 \\
5.65\end{array}$ & $\begin{array}{l}2.15 \\
4.41 \\
3.78\end{array}$ & $\begin{array}{l}3.78 \\
4.87 \\
9.40\end{array}$ & $\begin{array}{l}4.18 \\
4.74 \\
\text { S. } 39 \\
\end{array}$ & $\begin{array}{l}1.52 \\
1.32 \\
6.83 \\
\end{array}$ & $\begin{array}{l}2.50 \\
2.39 \\
2.65 \\
\end{array}$ & $\begin{array}{l}1.56 \\
1.35 \\
2.57 \\
\end{array}$ & $\begin{array}{ll}3.68 & 5 \\
2.93 & 6 \\
4.86 & 8 \\
\end{array}$ & $\begin{array}{l}5.95 \\
6.21 \\
8.32 \\
\end{array}$ & $\begin{array}{l}1.92 \\
.65 \\
2.47 \\
\end{array}$ & $\begin{array}{l}4.36 \\
4.21 \\
6.01 \\
\end{array}$ & $\begin{array}{l}3.16 \\
3.31 \\
5.23 \\
\end{array}$ \\
\hline Avg.... & 1.77 & 3.81 & 4.36 & 6.27 & 2.52 & 6.88 & 5.07 & 4.633 & 3.24 & 4.14 & 4.27 & 3.30 & 6.64 & 5. 29 & 3.54 & 2.47 & 2.20 & 4.046 & 6.77 & 1.83 & 5.23 & 4. 13 \\
\hline \multicolumn{23}{|c|}{ Runoff } \\
\hline $\begin{array}{l}\text { Gila River at head of Safford } \\
\text { Valley... }\end{array}$ & 0.18 & 0.20 & 0.43 & 0.59 & 0.17 & 0.66 & 0.41 & 0.27 & 0.17 & 0.28 & 0.34 & 0.12 & 0.68 & 0.13 & 0.18 & 0.10 & 0.08 & 0.15 & $0.88^{\prime}$ & 0.05 & 0.63 & 0.30 \\
\hline
\end{tabular}


small to be identified by the methods used. A more detailed approach than that used in this study would be necessary in order to demonstrate that a small change occurred.

The double-mass relation of computed summer runoff to measured summer runoff is shown in figure 10 . The computed summer runoff of figure 10 is from the relation : computed summer runoff $=0.00052$ (measured summer precipitation $)^{2.8}$. Several changes or trends, as defined in the double-mass relation of runoff to precipitation, are indicated. The correlation between summer precipitation and summer runoff is poor-the index of correlation is 0.73 , and the standard error of estimate is $0.30 \mathrm{log}$ unit-and the changes or trends in figure 10 may not be real. Instead, they may be due to poor definition of the true relation between runoff and precipitation. After 1935, however, the changes apparently correspond in time to changes in the relation of runoff to precipitation observed in a similar analysis made for the Cornfield Wash area in northwestern New Mexico about 70 miles west of Santa Fe (Burkham, 1966). Changes in the runoff-precipitation ratio in the Cornfield Wash area were attributed to changes in intensity of summer precipitation. An unusually large number of frontal storms having low-intensity precipitation, which occasionally move through the Southwest during September and October, may have caused the decrease in the ratio of runoff to precipitation.

In summary, this study suggests that no continuous decline in the ratio of runoff to precipitation for 191662 occurred in the Gila River basin above the head of Safford Valley. Relatively short periods having a reduced ratio of runoff to precipitation have occurred in the summer, which may be due to a change or shift in the predominance of a storm pattern-for example, a change from thunderstorms, which have typically high rates of precipitation, to frontal storms, which have typically low rates of precipitation.

Although no changes or trends in the ratio of runoff to precipitation are indicated, some may have occurred. A more detailed approach than that used in this study would be necessary to identify them.

\section{WATER LOSS IN SAFFORD VALLEY}

The decrease in streamflow at San Carlos since 1920 may be due to an increase in the use of surface water for irrigation in the Gila River basin. Comparative analyses of the amounts of surface water lost annually in the Safford Valley have been made to determine if progressively larger amounts of water were consumptively used during the period 1920-64. The native vegetation and cultivated crops and the farming methods used in Safford Valley are somewhat similar to those of upstream valleys; therefore, the streamflow losses in Safford Valley should be indicative of the streamfow losses in upstream valleys. In the Safford Valley, streamflow losses are due to direct evaporation from the water surface and seepage into the alluvium underlying the valley. Water diverted for irrigation is lost by diract evaporation, seepage, or is returned to the river as surface flow.

Water from the Gila River has been used for irrigation in the Safford Valley since about 1865 ; by $1 \subseteq 20$, about 32,500 acres was under cultivation (Cushman and Halpenny, 1955), but there has been relatively little change in irrigated acreage in the last 45 years. The irrigable area is limited by natural conditions, and the area irrigated with surface water is limited effectively by the Gila River decree of 1935 (Thomas and others, 1963 , p. 29). The small amount of added acreage has been mainly along the flood plain, where the native vegetation has been replaced by cultivated crops. Although the amount of irrigated acreage has not increased appreciably, increased use of the cultivated lend in the last 45 years may require more surface water for irrigation.

The amount of surface-water depletion in the Safford Valley in any year depends on several factors-timeliness of rainstorms during irrigation seasons, type of crops grown, and the depth to ground water. The changes in the use of ground water by flood-plain vegetation may cause changes in the amount of surfecewater loss.

Apparently no depletion-difference between Gila River flow at head of Safford Valley and at San Carlosin streamflow occurred in the Gila River in the Safford Valley through about 1920 . This would mean that the input from different sources-such as tributary streams, ground-water discharge into the river channel, and precipitation on the river surface-equaled or exceeded the losses. With the exception of 1941 , however, a trond toward slightly greater annual depletion occurred from 1920 through 1964 (fig. 11).

Average trends with time in surface-water depletion within the Safford Valley were analyzed using the difference between surface-water inflow to the valley and surface-water outflow. Figure 12 indicates that the 10year progressive average annual reduction in streamf 'ow ranged from about 10,000 to 60,000 acre-feet in the Gila River within the Safford Valley.

In the Safford Valley, the studies of trends in depletion of surface flow indicate that the years of least depletion correspond to the wet periods of record, and, inversely, that the years of greatest depletion correspond to the years of least flow. This implies either more use of surface water during dry years, or a curvilinear ef ect 


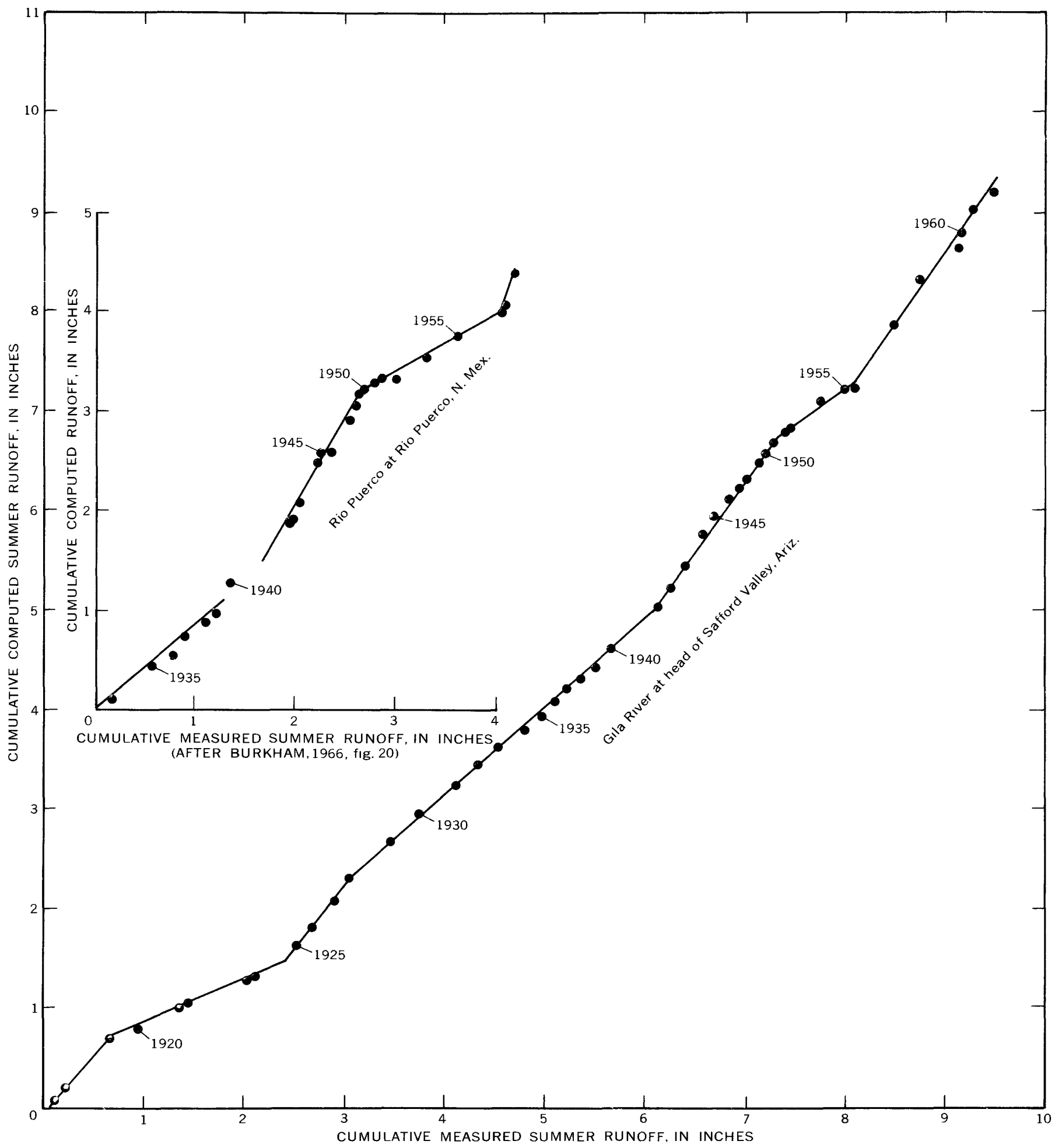

Figure 10.-Double-mass relations of measured summer runoff versus computed summer runoff, Gila River at head of Safford Valley, near Solomon, Ariz., and Rio Puerco at Rio Puerco, N. Mex. Computed summer runoff of Gila River at head of Safford Valley $=0.00052$ (measured summer precipitation) ${ }^{2.8}$; computed summer runoff of Rio Puerco at Rio Puerco= 0.0038 (measured summer precipitation). ${ }^{2}$ 


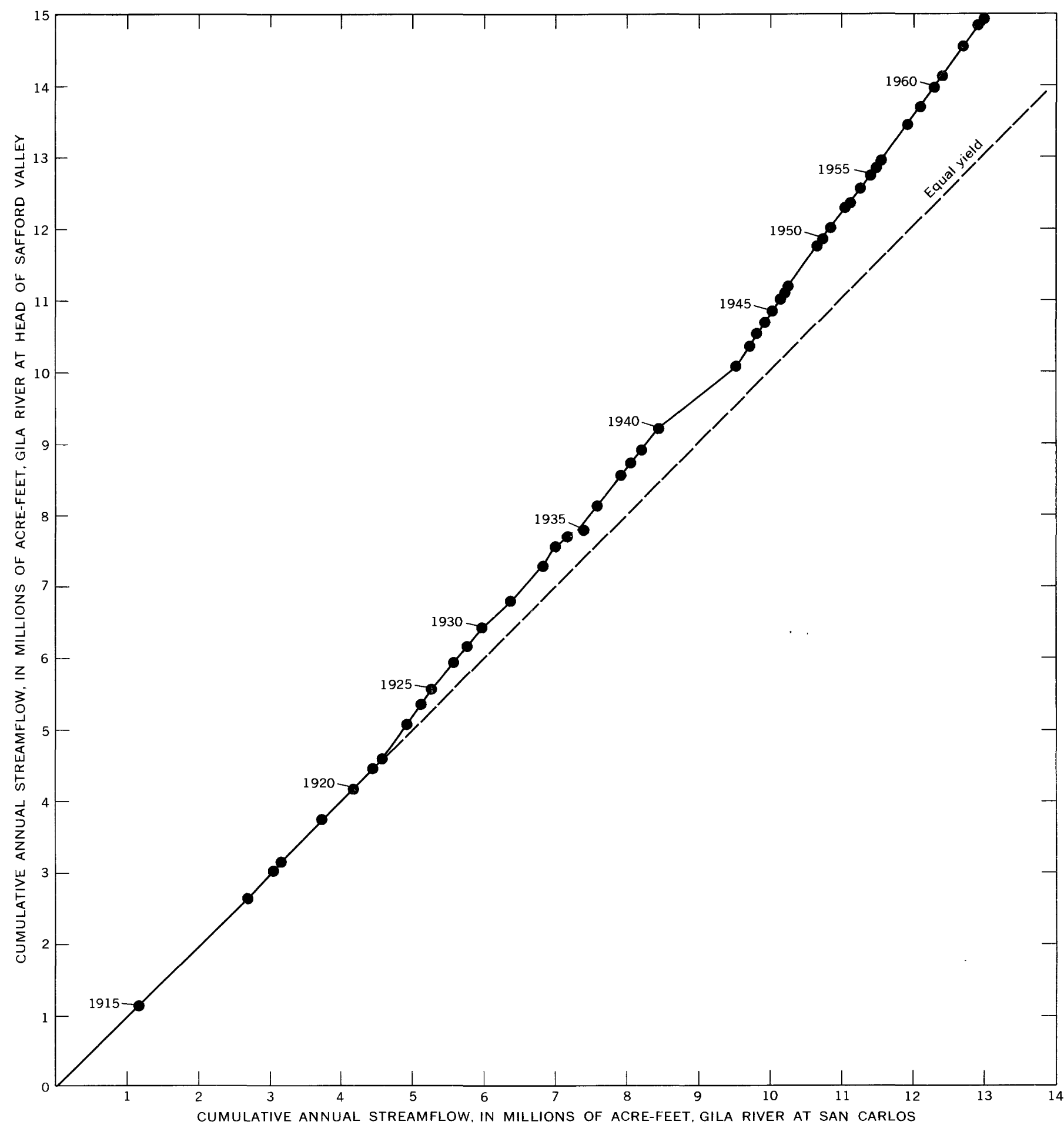

FigURE 11.-Double-mass relation of measured streamflow at Gila River at head of Safford Valley, near Solomon, Ariz., and at Gila River at San Carlos, Ariz., 1915-64. 


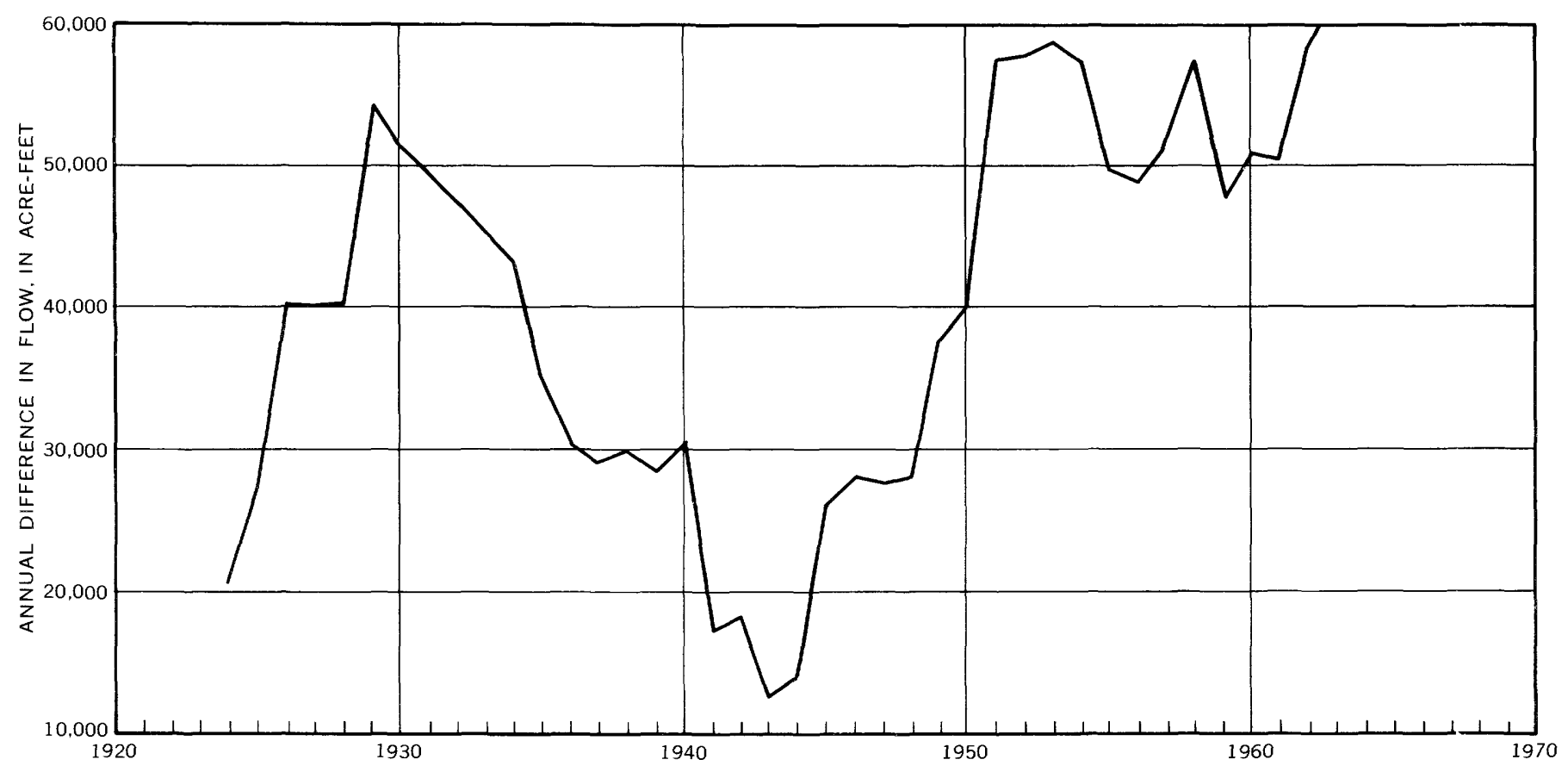

Frgure 12.-Progressive 10-year average reduction in annual streamflow, Gila River at head of Safford Valley, near Solomon, Ariz., and Gila River at San Carlos, Ariz. Each 10-year average is plotted at the year that ends the decade.

from the precipitation-runoff relation of water yields from tributaries, or, perhaps, both. Tributary inflow generally adds appreciable amounts of water to the Gila River during wet years and almost none during dry years. The relation of surface-water loss, by seepage and evaporation, to rate of surface flow in the Gila River is probably curvilinear.

An attempt was made to eliminate possible curvilinear effects of the relation of streamflow losses to the rate of river flow by using the method previously described in the section "Precipitation-runoff relations." The average relation between annual streamflow at head of Safford Valley and that at San Carlos (fig. 13) is given by the equation: streamflow at San Carlos $=0.037$ (measured flow at head of Safford Valley) ${ }^{1.24}$. Figure 14 is a double-mass comparison of the computed annual streamflow and the measured annual streamflow for Gila River at San Carlos. As streamflow records were not available for Gila River at San Carlos for 1928-29, the flow of 1930 was added to that of 1927 in order to complete the graph. The double-mass comparison of annual computed streamflow with gaged streamflow for Gila River at San Carlos indicates a fairly consistent relation since 1914 .

Independent studies of the curvilinear effects for summer and winter flows were made for the gaging stations at head of Safford Valley and at San Carlos. The results of the studies indicate no continuous inconsist- ency in the relation of streamflow at the head of Safford Valley to that at San Carlos.

In order to place some confidence in the reality of no apparent change in the relation of inflow to outflow, a two-sided Student's $t$ test and an $F$, or variance ratio, test were applied, respectively, to the means ard variances of the annual depletion, or difference between the flows of the Gila River where it enters and where it leaves the Safford Valley. The streamflow data for periods 1920-30 and 1950-60, which were used for the confidence test of no apparent change in the runoff-precipitation relation, also were used in these tests. The mean precipitation was about the same for the two periods. The null hypothesis was made that the two samples were from the same population. The means of the annual difference between the Gila River inflow to and outflow from Safford Valley were about 51,200 and 51,000 acre-feet, respectively, for 1920-30 and 1950-60. The streamflow means for the two periods were not significantly different at the 1 percent level, as shown by the two-sided Student's $t$ test, and the difference between the variances was not significant at the 5-percent level, as shown by the variance ratio test.

As indicated previously (p. B13), the difference in the amount of surface flow entering and learing the Safford Valley by the Gila River does not represent the total loss of surface flow within the valley; direct precipitation on the water surface and tributar: inflow 
add to the river flow. A simple budget can be used to evaluate the total loss of surface water within the Safford Valley. As applied to the valley, the budget stated in equation form is:

or

$$
Q_{I G}+Q_{I T}+P=Q_{O G}+E_{ \pm} Q_{I S}
$$

in which

$$
E_{ \pm} Q_{I S}=Q_{I G}+Q_{I T}+P-Q_{O G}
$$

$Q_{I G}=$ inflow of the Gila River,

$Q_{I T}=$ inflow of tributaries to the valley,

$P=$ precipitation on all water surfaces within the valley,

$Q_{O G}=$ outflow of the Gila River,

$E=$ direct evaporation from all water surfaces within the valley, and

$Q_{I S}=$ net interchange between surface and subsurface water.

The long-term average loss of surface flow, $E \pm Q_{I S}$, is evaluated for 1938-61 because more information on tributary flow was available in that period than in any other period of comparable length. The Gila River inflow to the Safford Valley is that gaged at the head of Safford Valley, and the Gila River outflow is that gaged at Calva. The precipitation that falls on the water surface is a small item in the budget and is estimated to be 350 acre-feet annually for 1938-61. The inflow from 2,192 square miles of the total 3,584 square miles drained by tributaries to Safford Valley is measured at the gaging station on San Simon River near Solomon.

An estimate of the ungaged flow from the remaining 1,392 square miles drained by tributaries was made by using the simple relation of measured flow to the size of the contributing area at 16 gaging stations within or near the Gila River basin above Coolidge Dam (table 3 and fig. 15). As the ungaged inflow to the Safford Valley probably occurs mainly in the summer, the fow during that season is used in the correlation of runoff to size of contributing basin. The index of correlation for the relation is 0.89 (determined graphically), and the standard error of estimate is $0.37 \log$ unit.

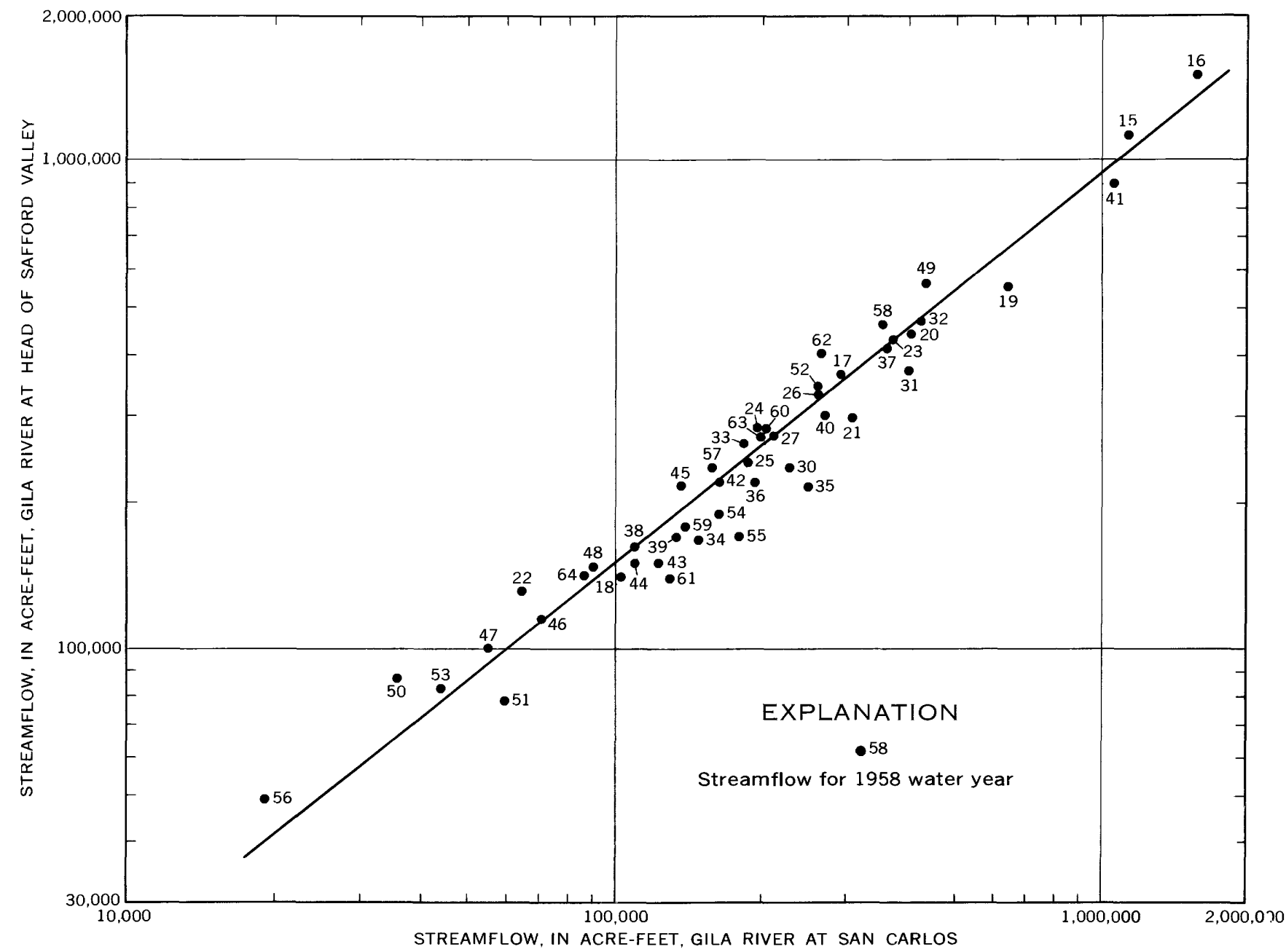

FIGURE 13.--Relation of annual streamflow at Gila River at head of Safford Valley, near Solomon, Ariz., and at Gila River at San Carlos, Ariz., 1915-64. 


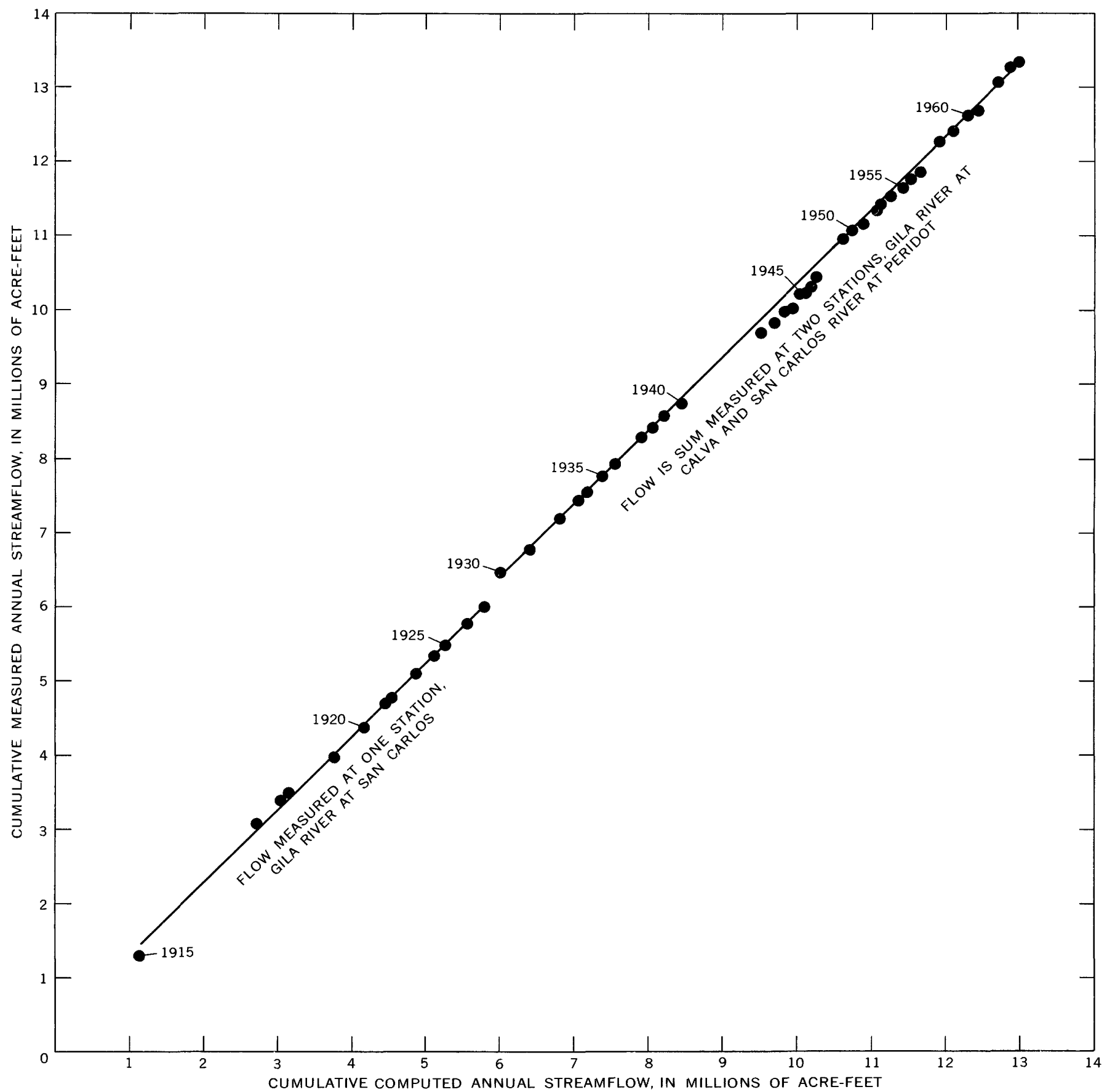

FIGURE 14.-Double-mass relation of computed annual streamflow and measured annual streamflow, Gila River at San Carlos. Ariz. Streamflow records not available for 1928-29. Computed streamflow $=0.037$ (measured flow at head of Safford Valley) ${ }^{1+24}$. 


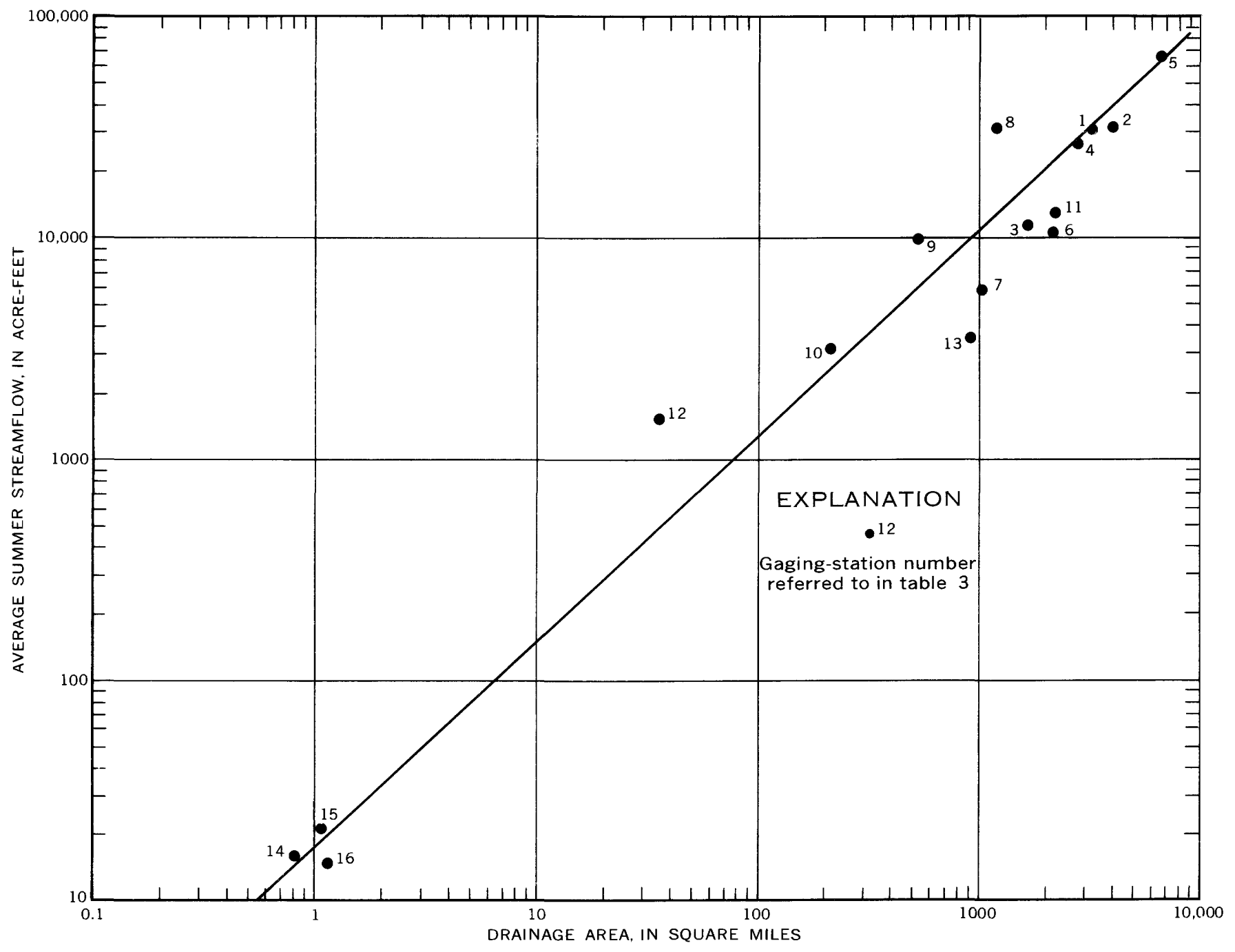

Figure 15.-Relation of summer streamflow to size of basin for watersheds in southeastern Arizona, $1938-61$.

TABLE 3.-Mean summer streamflow at gaging stations in or near the Gila River basin, 1938-61

\begin{tabular}{|c|c|c|c|c|c|c|c|}
\hline \multirow{2}{*}{$\begin{array}{l}\text { Plot No. } \\
\text { (see } \\
\text { fig. 15) }\end{array}$} & \multirow{2}{*}{ Gaging station } & \multicolumn{3}{|r|}{ Location } & \multirow{2}{*}{$\begin{array}{l}\text { Land-surface } \\
\text { altitude } \\
\text { (feet above } \\
\text { mean sea } \\
\text { level) }\end{array}$} & \multirow{2}{*}{$\begin{array}{c}\text { Drainage } \\
\text { area } \\
(\mathbf{s q ~} \mathrm{mi})\end{array}$} & \multirow{2}{*}{$\begin{array}{c}\text { Mean } \\
\text { summer } \\
\text { streamfl ow } \\
\text { (acre-fi) }\end{array}$} \\
\hline & & Lat (N.) & Long (W.) & Section, township, and range & & & \\
\hline 1 & Gila River below Blue Creek, near Virden, & $32^{\circ} 38^{\prime} 55^{\prime \prime}$ & $108^{\circ} 50^{\prime} 45^{\prime \prime}$ & SE1/4SW1/4 sec. 18, T. 19 S., R. 19 W.- & 3,875 & 3,203 & 31,739 \\
\hline & $\begin{array}{l}\text { Gila River near Clifton, Ariz } \\
\text { San Franeisco River near Glenwood, N. } \\
\text { Mex. }\end{array}$ & $\begin{array}{l}32^{\circ}{ }^{\circ} 7^{\prime}, 50^{\prime \prime} \\
33^{\circ} 15^{\prime} 05^{\prime \prime \prime}\end{array}$ & $\begin{array}{l}109^{\circ} 1{ }^{\prime} 1{ }^{\prime \prime \prime} \\
108^{\circ} 52^{\prime} 40^{\prime \prime \prime}\end{array}$ & $\begin{array}{l}\text { SW1/4SW1/4 sec. 30, T. } 5 \text { S., R. } 30 \mathrm{E} \\
\text { NE1/4NW1/4 Sec. } 23, \text { T. } 12 \text { S., R. } 20 \text { W. }\end{array}$ & $\begin{array}{l}\mathbf{3}, 339 \\
4,552\end{array}$ & $\begin{array}{l}4,010 \\
1,653\end{array}$ & $\begin{array}{l}32,184 \\
11, \mathbf{e 7 8}\end{array}$ \\
\hline & $\begin{array}{l}\text { San Francisco River at Clifton, Ariz } \\
\text { Gila River at head of Saftord Valley, near } \\
\text { Solomon, Ariz. }\end{array}$ & $\begin{array}{l}33^{\circ} 02^{\prime} 50^{\prime \prime} \\
32^{\circ} 52^{\prime} 10^{\prime \prime}\end{array}$ & $\begin{array}{l}109^{\circ} 17^{\prime} 50^{\prime \prime} \\
109^{\circ} 30^{\prime} 40^{\prime \prime \prime}\end{array}$ & $\begin{array}{l}\text { NW1/NEY//4 sec. 31, T. } 4 \text { S., R. } 30 \text { E. } \\
\text { SE1/4NE1/4 sec. 31, T. } 6 \text { S., R. } 28 \text { E.- }\end{array}$ & $\begin{array}{l}3,431 \\
3,065\end{array}$ & $\begin{array}{l}2,766 \\
7,896\end{array}$ & $\begin{array}{l}27,922 \\
68,250\end{array}$ \\
\hline $\begin{array}{r}6 \\
7 \\
8 \\
9 \\
10 \\
11 \\
12 \\
13 \\
14 \\
15 \\
16\end{array}$ & 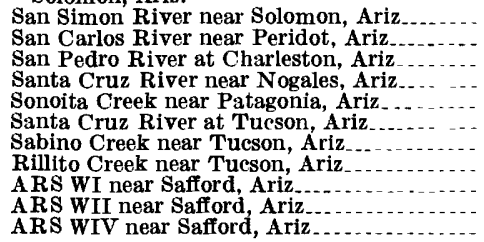 & 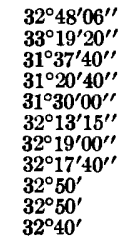 & $\begin{array}{l}109^{\circ} 38^{\prime} 19^{\prime \prime} \\
110^{\circ} 66^{\prime} 50^{\prime \prime} \\
110^{\circ} 10^{\prime} 30^{\prime \prime} \\
110^{\circ} 51^{\prime \prime} 5^{\prime \prime} \\
110^{\circ} 49^{\prime} 00^{\prime \prime} \\
110^{\circ} 58^{\prime} 50^{\prime \prime} \\
110^{\circ} 48^{\prime} 35^{\prime \prime} \\
110^{\circ} 59^{\prime} 05^{\prime \prime} \\
109^{\circ} 3^{\prime} \\
110^{\circ} 00^{\prime} \\
109^{\circ} 40^{\prime}\end{array}$ & 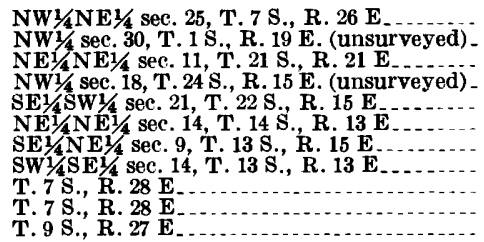 & $\begin{array}{l}2,960 \\
2,583 \\
\mathbf{3}, 954 \\
\mathbf{3}, 702 \\
\mathbf{3}, \mathbf{8 1 8} \\
2,323 \\
2,720 \\
2,284 \\
\mathbf{3}, 100 \\
3,100 \\
\mathbf{3}, 100\end{array}$ & $\begin{array}{r}2,192 \\
1,027 \\
1,219 \\
533 \\
209 \\
2,222 \\
35.5 \\
918 \\
.81 \\
1.07 \\
1.13\end{array}$ & $\begin{array}{r}10,930 \\
5, \mathrm{gr6} \\
32,124 \\
10,27 \\
3,100 \\
13,427 \\
1,526 \\
\mathbf{3}, 547 \\
16.2 \\
21.3 \\
14.7\end{array}$ \\
\hline
\end{tabular}


The results of the budget study for 1938-61 (table 4) indicate that the total annual input to Safford Valley was about 257,000 acre-feet and that the average annual outflow at Calva was about 145,000 acre-feet. Therefore, the average annual loss of surface water within the valley was about 112,000 acre-feet, or about 2,040 acre-feet per mile per year for the 55-mile length of the valley.

The mean annual losses for 5 -year periods beginning in 1938 also were computed (table 4). They increased from about 85,600 acre-feet for $1938-43$ to about 124,000 acre-feet for 1958-63; the difference of 38,400 acre-feet was 34 percent of the average annual loss for 1938-61. If losses are computed on an annual instead of a 5-year basis, the range expressed in percent of the average for $1938-61$ is even greater.

An average annual water loss of about 1,360 acre-feet per mile occurred in a 5.7-mile-long reach, from near Bylas gaging station to the at Calva gaging station (fig. 1), of the Gila River Phreatophyte Project for 1963-65; in 1963, 2,110 acre-feet per mile; in 1964, 1,270 acre-feet per mile; and in 1965, 680 acre-feet per mile. The loss is the difference between the sum of the Gila River flow plus tributary flow minus outflow from the Gila River.

The streamflow-depletion studies within the Safford Valley do not indicate any major increase in the annual quantity of surface water retained within the Safford Valley for $1920-62$, although the year-to-year variation is relatively large. The curvilinear relation of precipitation to runoff from tributaries and (or) the curvilinear relation of streamflow rates to losses resulted in an apparent increase in the amount of surface water used in the valley during the years of low surface flow. When the streamflow data are adjusted for the effects of the curvilinear relations, the inconsistency in the doublemass relation of inflow to outflow is not apparent.

In summary, because surface flow in the Gila River is depleted by evaporation and seepage, it can be assumed that the net effects of factors that control evaporation and seepage have not changed in magnitude enough that the change in surface-water use, if any, could be identified by the methods used in this report. A more elaborate study of the factors that control evaporation and seepage will be necessary to identify small changes, if any, since 1920 in the rate of surface water used or lost in the Safford Valley.

\section{MAJOR FLOODS}

Catastrophic floods exert tremendous forces on objects in their paths. Often, these forces are of such magnitude that the debris and vegetation on the flocd plain are flushed downstream, and the stream channel is altered extensively. All the recorded major flood " on the Gila River occurred in the period late September through February (fig. 16). The principal causes were (1) widespread heavy rainfall of long duration, (2) warm weather after a large snow accumulation. or (3) widespread rainfall on snow. The following hirtory of flooding provides a background for channel-change studies underway as part of the Gila River F'reatophyte Project.

Authoritative information on Gila River floods prior to 1905 is scarce. Although there are historical references to floods in 1833, 1862, 1869, 1880, 1884, 18\&9, 1891, 1895 , and 1896, the discharge of none of thes? floods was measured. Most reports on the earlier major floods are newspaper accounts, and the magnitudes of the floods and extent of flood damage differ with the reporter. According to Davis (in Lippincott, 1900, p. 35), the flood of 1891 near Florence (75 miles downstream from Coolidge Dam) probably was the greatest in 25 or 30 years, and, according to Smith and Heckler (1955, p. 61), the flood of 1905 at the same site exceeded that of 1891. Thus, the relative magnitudes of the floods from 1861 through 1905 are approximated for the site near Florence. In this report the description of major floods begins with that in 1891, the first for which any quantitative data are available.

TABLE 4.-Estimated surface-water loss from the Gila River in the Safford Valley

[Values are annual means, in acre-feet, for specified periods]

\begin{tabular}{|c|c|c|c|c|c|c|c|}
\hline \multirow{2}{*}{ Period } & \multirow{2}{*}{$\begin{array}{c}Q_{I G}=\text { surface inflow, } \\
\text { Gila River }\end{array}$} & \multicolumn{2}{|c|}{$Q_{t T}=$ tributary inflow } & \multirow{2}{*}{$\begin{array}{l}P=\text { precipitation } \\
\text { on water surface }\end{array}$} & \multirow{2}{*}{ Total input } & \multirow{2}{*}{$\begin{array}{c}\text { Qog=surface } \\
\text { outflow, Gila } \\
\text { River at Calva }\end{array}$} & \multirow{2}{*}{$\begin{array}{c}E+Q_{I S}=\text { evaporation }+ \text { net } \\
\text { interchange betwee } \text { surface } \\
\text { and subsurface water }= \\
Q_{I G}+Q_{I T}+P-Q_{O G}\end{array}$} \\
\hline & & $\begin{array}{l}\text { San Simon } \\
\text { River }\end{array}$ & $\begin{array}{c}\text { Ungaged } \\
\text { tributaries }\end{array}$ & & & & \\
\hline $\begin{array}{l}1938-61 \\
1928-33 \\
1933-38 \\
1938-43 \\
1943-48 \\
1948-53 \\
1953-58 \\
1958-63\end{array}$ & $\begin{array}{l}231,120 \\
\mathbf{3 3 5}, 800 \\
244,040 \\
352,300 \\
144,560 \\
234,128 \\
221,966 \\
263,402\end{array}$ & $\begin{array}{r}11,240 \\
10,672 \\
8,018 \\
7,802 \\
18,774 \\
7,868\end{array}$ & $\begin{array}{r}14,390 \\
149,500 \\
127,000 \\
16,500 \\
11,300 \\
14,000 \\
14,600 \\
10,000\end{array}$ & $\begin{array}{l}350 \\
315 \\
274 \\
262 \\
206 \\
158 \\
242 \\
250\end{array}$ & $\begin{array}{l}257,100 \\
385,615 \\
271,314 \\
379,734 \\
164,084 \\
256,088 \\
248,582 \\
281,520\end{array}$ & $\begin{array}{r}145,043 \\
272,825 \\
176,780 \\
294,144 \\
75,450 \\
145,902 \\
137,234 \\
157,478\end{array}$ & $\begin{array}{r}112,057 \\
112,790 \\
94,534 \\
85,590 \\
88,634 \\
110,186 \\
111,348 \\
124,042\end{array}$ \\
\hline
\end{tabular}

1 Includes estimates of flow in the San Simon River. 
FLOOD OF FEBRUARY 22, 1891

The flood of February 22, 1891, probably was the result of widespread rainfall on snow. No gaging stations were in operation at the time, but the magnitude of the flood can be estimated from information furnished by A. T. Colton, "a competent engineer" (Lippincott, 1900 , p. 36), for a site about 15 miles upstream from Florence. Davis (in Lippincott, 1900, p. 34-35) described the 1891 flood thusly:

The best evidence thus far obtained regarding past freshets on this river was kindly furnished by Mr. Albert T. Colton. The greatest rise so far recorded on the Gila River occurred on the 22d of February, 1891. Considerable evidence was obtained that no such flood has occurred since a date many years before the advent of the white man. Irrigating ditches supposed to be extremely old were overflowed and destroyed. Lands were overflowed that had retained no evidence of any previous inundation.

On June 12, 1892, about sixteen months after this flood, Mr. Colton found marks of high water on both banks of the river far above any of the ordinary freshets, which he attributed to the great flood. This point was about $3 \frac{1}{1}$ miles below the head of the Florence canal, or approximately 6 miles below the Buttes. With his level he took a cross section of the river at this point and measured the slope of the channel. The cross section he obtained was 6,600 square feet. The slope measured was 10.56 feet per mile. The channel was sandy and free of brush or large boulders or other obstructions for a distance of 300 feet above and 300 feet below the cross section. This information, meager as it is, is the best we have upon which to estimate the discharge of the river at that time.

The difficulty in obtaining correct results of this discharge lies in the uncertainty of the retarding effect of the channel upon the flow of the water. This retarding effect in a rough river bed is very great. Assuming this quantity as small as it could possibly be, a computation of the discharge was made, using Kutter's formula. The factor of roughness designated in the formula as " $n$ " was taken as 0.025 . Not that this was considered the correct factor, as it is almost certainly too small, but by assuming the smallest possible value of " $n$ " we obtain the largest discharge, and it is the largest discharge that should be provided for in the construction of a spillway. It is thought, therefore, that this computation will give conservative results, and that a spillway based upon the discharge obtained would be safe. The result obtained was 102,566 cubic feet per second.

Although Colton's indirect discharge measurement would not meet present-day requirements for a good indirect measurement, it certainly is of the right order of magnitude. The "conservative" results based on the $n$ of 0.025 may not be conservative at all, as recent studies have shown that the $n$ for a sand channel may be as low as 0.010. Furthermore, the use of the channel slope instead of the energy gradient for determining discharge may not have introduced a great error; some researchers (Dawdy, 1961, p. 4) of the hydraulics of sand-channel streams have assumed the energy-gradient slope to be equal to the channel slope. The most undesirable part of Colton's estimate is that he used only one cross section in his measurement.
How closely the estimate of 102,566 cfs for the Florence site approximates the peak discharge past $\mathrm{rp}$ stream points is not known. Olmstead (1919, p. 64- 65$)$ presented evidence that the peak discharge of the Gila River below its confluence with the San Francisco River was substantially greater. He stated that the peak discharge of the San Francisco at Clifton, although not measured, was the second highest of record and that the first and third largest flows recorded at that site prior to 1919 were $143,450 \mathrm{cfs}$ and $107,870 \mathrm{cfs}$, respectively. Moreover, according to Patterson and Somers (19\%6, p. 394), the flow of the Gila River a short distance upstream from the confluence may have exceeded 28,000 cfs.

\section{FLOOD OF SEPTEMBER-OCTOBER 1895}

The flood during the week of September 27 to $\mathrm{Oc}^{+}$ber 4,1895 , was the result of 4 days of continual rain and caused considerable damage near Safford and Solomon. According to the Graham County Guardian (Oct. 3, 1895), the Gila River was nearly half a mile wide. A large part of Solomon was flooded by the San Simon River, but, although flooding was severe at Safford and Solomon, it probably was not of a magnitude to cause widespread damage. The precipitation data available, although meager, do not indicate widespread flooding.

\section{FLOOD OF OCTOBER 1896}

Another locally destructive flood similar to that of October 1895 occurred near Safford and Solomon d'vring the week of October $9-16,1896$. It was a result of 3 days of continual rain (Graham County Guardian, Oct. 18, 1896), and Solomon again was flooded by water from the San Simon River.

\section{FLOOD OF JANUARY 1905}

The flood of January 10-11, 1905, caused extensive damage because it was the first major flood after a re'atively long period of economic development on the flood plain. It was the direct result of two general rains. The first, early in December 1904, was continuous for 4 days at Solomon. It undoubtedly left the watershed in a thoroughly wetted condition and also left a cover of snow in the higher parts of the basin. The second rain was in January 1905. It lasted for 2 days and produced more than 3 inches of precipitation at Safford (Graham County Guardian, Jan. 13, 1905). Flooding of the San Francisco River not only caused severe damage but cost the lives of three persons at Clifton; flooding of the Gila resulted in severe damage at Duncan, Solomon, and Safford. The damage along the entire reach of the Gila River in Arizona probably exceeded $\$ 1,000,000$ (Graham County Guardian, Jan. 21, 1905). 

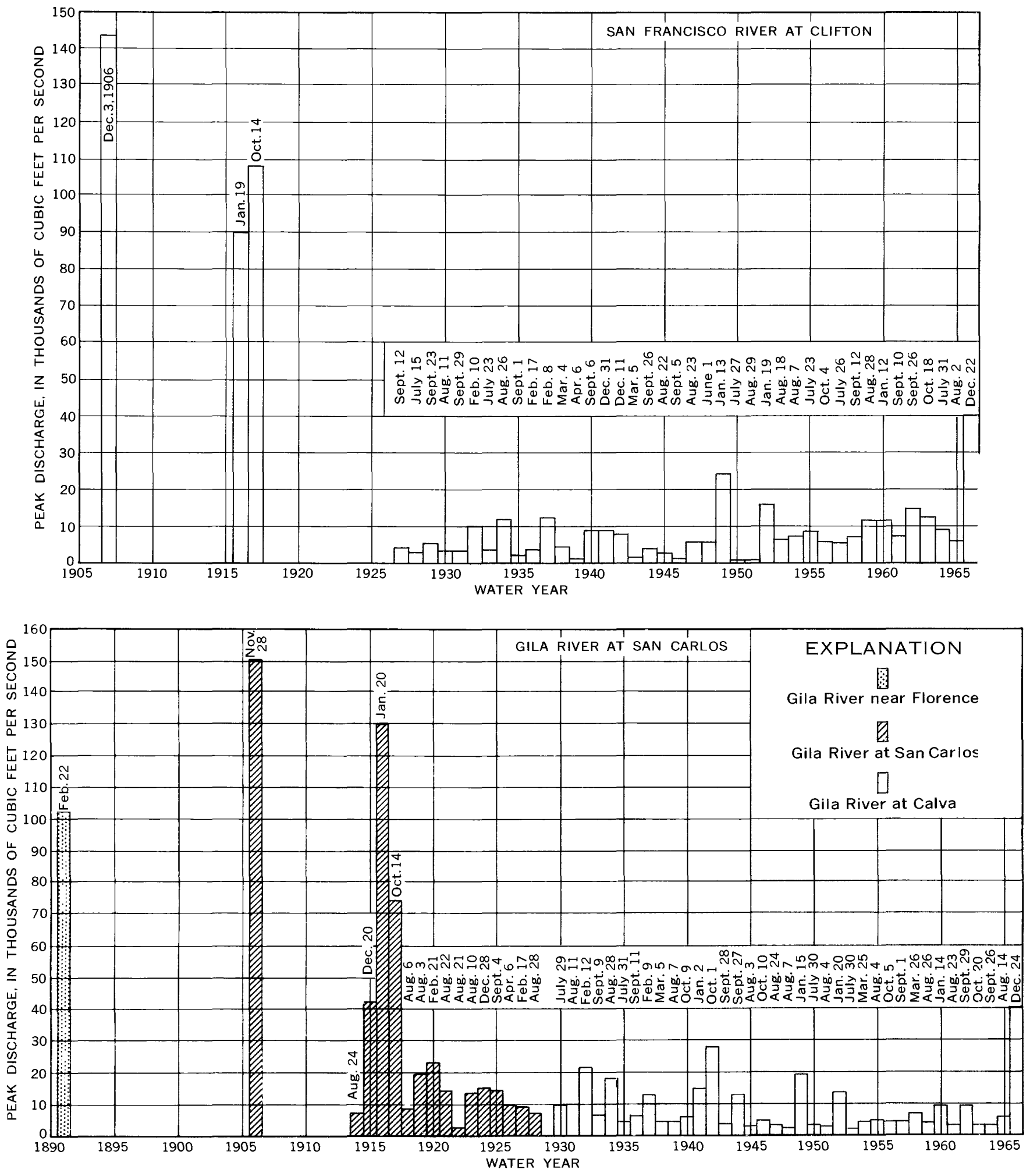

Figure 16.-Annual floods of record in the Gila River basin (above and facing page). 

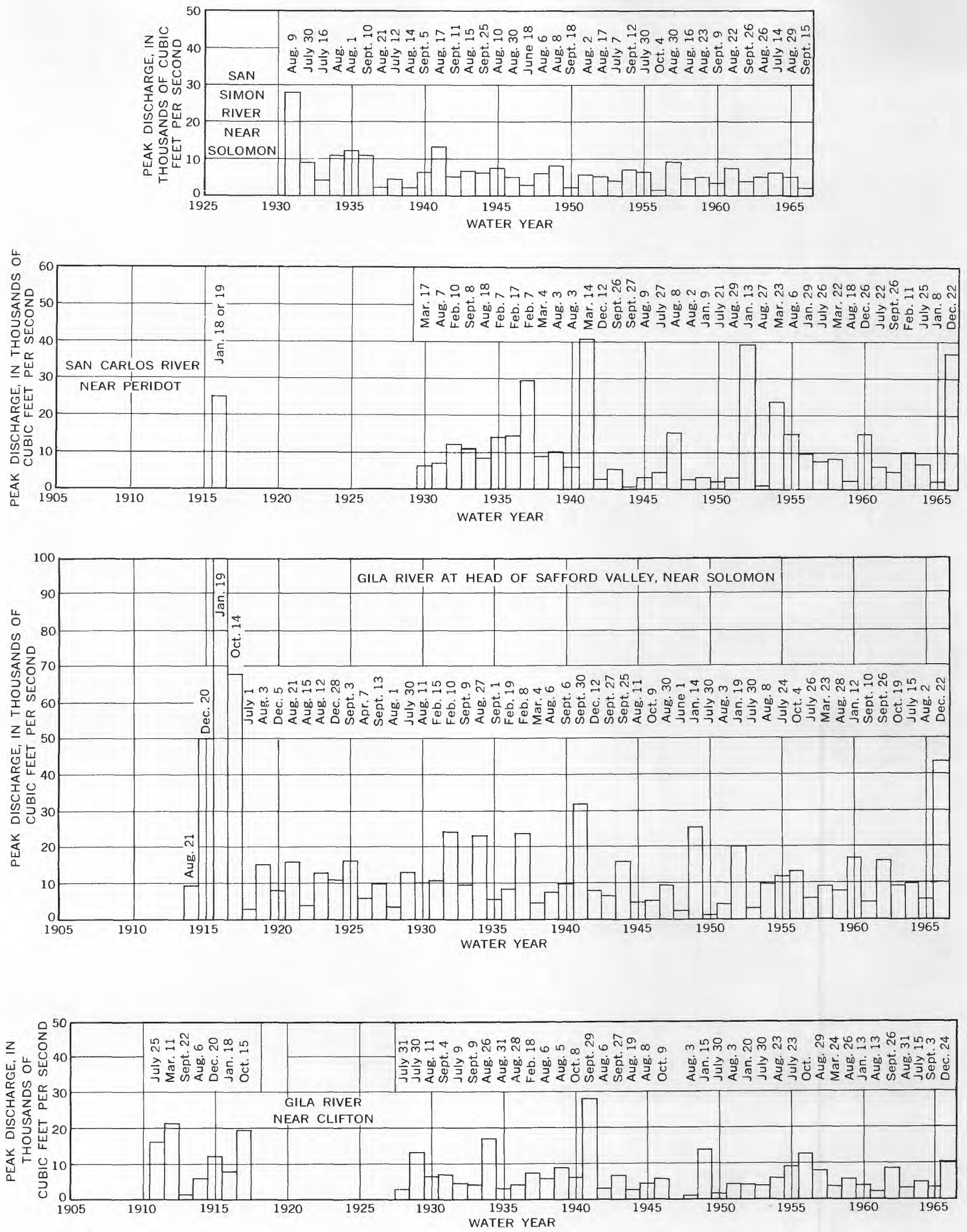
In addition to the flood in January, there were high flows in February, March, and April (Olmstead, 1919, p. 19). The gaging station on the Gila River at San Carlos, which was washed away in January and was reestablished in February, was washed away again in March.

\section{FLOOD OF NOVEMBER 28, 1905}

Three different weather disturbances during November 1905 and the previous exceptionally high winter and spring precipitation resulted in a flood on the 28th of that month (Graham County Guardian, December 1, 1905). The precipitation of the previous spring and winter had left the soil in much of the basin nearly saturated. The first of the disturbances in November was a spell of low-intensity precipitation, most of which was absorbed by the soil. Then a storm from November 21-23 provided additional soil moisture and a moderately heavy snow cover. Another storm, November $25-28$, resulted in heavy rain that evidently melted much of the snow. Because the soil was already

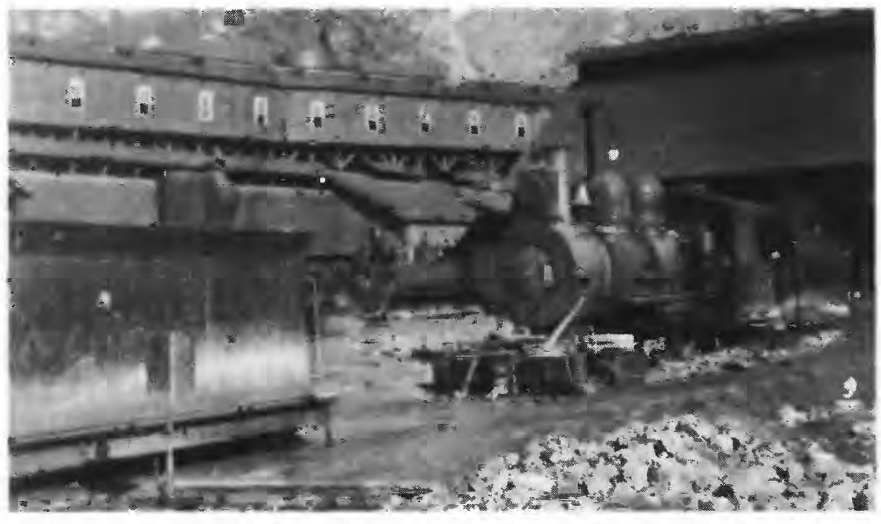

A

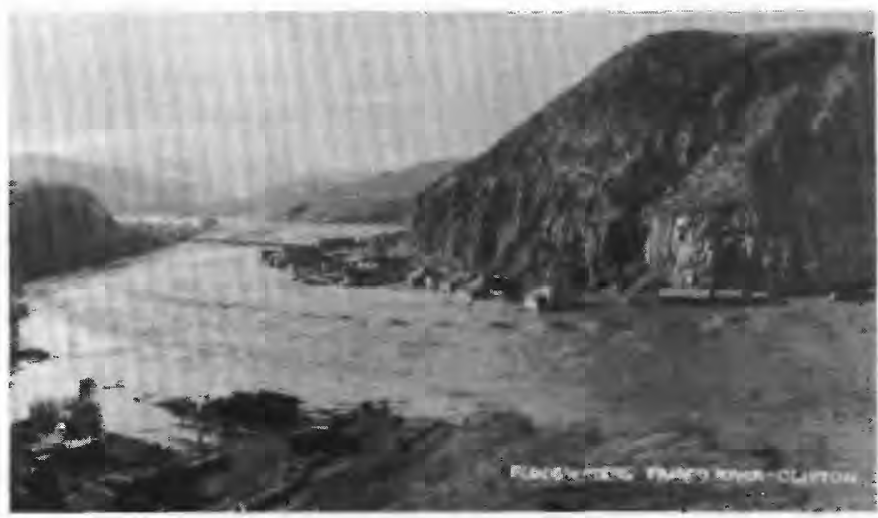

$B$ saturated, this rain and the snowmelt resulted in a high rate of overland runoff.

Overflow from the San Francisco River flooded part of Clifton (fig. 17). Although damage along the Gila River was considerable, it was less than in the preceding spring because the floods earlier in the year had widened and deepened the river channel and thus facilitated the discharge of later floodwater. The estimated peak discharge of the Gila River at San Carlos was 150,000 cfs (Smith and Heckler, 1955, p. 61) and near Florence was 190,000 cfs (Corps of Engineers, 1914, p. 84).

\section{FLOOD OF DECEMBER 3, 1906}

Fanctors contributing to the flood of December 3, 1906, were soil moisture carried over from the previous year, additional soil moisture resulting from two moderate storms during the preceding month, and runoff from precipitation that began on December 1. According to the Corps of Engineers (written commun., 1945), two different storms were the immediate cause of the

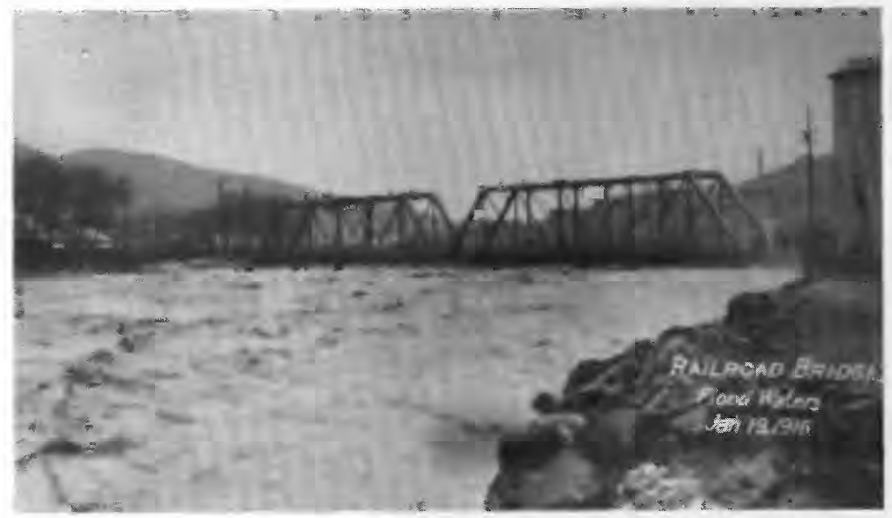

C

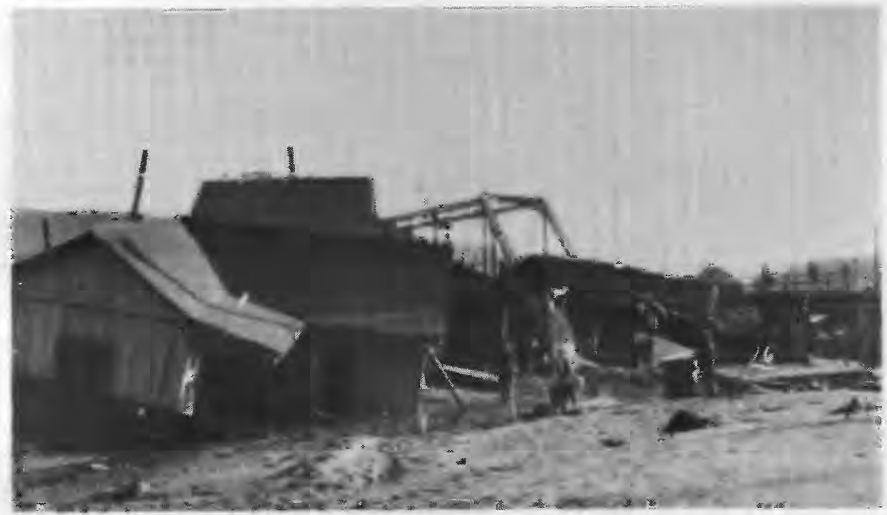

$D$

Figure 17.-Floods at Clifton, 1905-16. $A$, Railroad station after flood of November 28, 1905. B, Flood of December 3, 1906; looking downstream toward railroad bridge. $C$, Flood of January 19,1916 ; looking downstream toward railroad bridge. $D$, Houses and debris lodged against railroad bridge after flood of December 3, 1916. Photographs furnished by Risdon Studios, Clifton. 
flood-producing runoff. The first, which moved in from the Pacific Ocean, left snow on the mountains, and the second, which moved in from Mexico, resulted in warm rain. Although the precipitation was widespread, severe flooding was confined to the upper part of the basin.

The peak discharge of the San Francisco River at Clifton was estimated by Olmstead $(1919$, p. 64$)$ to have been $143,540 \mathrm{cfs}$, and it may have been the largest known flood at that location. Contributing to that peak was water that rushed down Chase Creek when a dam at Morenci failed. Several houses in Clifton were washed away, and soil was removed from many acres of farmland in that vicinity (fig. 17). 'The peak discharge probably decreased downstream, but no estimates of the flow at downstream points have been published.

\section{FLOODS OF DECEMBER 20, 1914, AND JANUARY 30, 1915}

After 8 years without a significant flood, the Gila River overflowed twice within a period of 6 weeks. The first of these floods occurred on December 20, 1914, and was caused by a storm that originated over the Pacific Ocean; moderate amounts of rain fell on a large area, and high-intensity rains fell locally (Corps of Engineers, written commun., 1945). The second, on January 30,1915 , probably was the result of rapidly melting snow.

The peak flow during the December flood was 50,000 cfs at the head of Safford Valley and 42,000 cfs downstream at San Carlos. The January flood had a peak flow of $48,000 \mathrm{cfs}$ at the head of Safford Valley.

\section{FLOODS OF JANUARY 18-20 AND 29, 1916}

A combination of climatological events set the stage for the floods that occurred January 18-20 and 29, 1916. The first of these was a heavy snowfall on most of the basin in early December 1915 . The snow at the lower altitudes soon melted, but a thick snow cover remained on the mountains when light rains fell on January 10-12. Evidently most of the rain was added to the moisture content of the snow, as runoff from the additional precipitation was negligible. Two storms, both originating over the Pacific Ocean, were the immediate causes of the two floods. The first, January 1521 , began with a warm rain that was followed by snow, and it was the warm rain, together with the earlier snow it melted, that caused the flooding on January 20. The second storm, January 25-30, was less severe and consisted mostly of warm rain that melted much of the remaining snow cover. The flood of January 29 resulted from the combined rain and snowmelt.

The earlier flood was the greater. The San Francisco River had a peak discharge of $90,000 \mathrm{cfs}$ at Clifton (fig. 17), and the Gila River had peaks of $100,000 \mathrm{cfs}$ and $130,000 \mathrm{cfs}$ at the head of Safford Valley and at San Carlos, respectively. On January 29 the peak discharge of the Gila River at the head of Safford Valley was a measured 28,000 cfs and at San Carlos was estimated by Smith and Heckler $(1955$, p. 61$)$ to have been 30,000 cfs. These floods may have been the most costly up to that time, owing to greater economic development of the flood plain. They were especially destructive in the lower Gila River basin.

\section{FLOOD OF OCTOBER 14-15, 1916}

The flood of October 14-15, 1916, was the direct result of rainfall from a storm that originated in the Gulf of Mexico. The storm passed over the Gila River basin on October 8-15 (Corps of Engineers, written commun., 1945) and produced an average of 5.10 inches of precipitation in the San Francisco drainage basin above Clifton. According to Olmstead (1919, p. 64), the storm caused the highest flows known to that time in the upper San Francisco River and Tularosa River.

The storm caused the San Francisco River to have an estimated peak flow of 107,870 cfs at Clifton (Olmstead, 1919, p. 64) and the Gila River to have recorded peak flows of $19,500 \mathrm{cfs}$ near Clifton, $67,900 \mathrm{cfs}$ at the head of Safford Valley, and 74,000 cfs at San Carlos. The large reduction in peak flow as the flood moved from Clifton to San Carlos indicates that the volume of the flood was relatively small.

\section{FLOOD OF SEPTEMBER 29-OCTOBER 1, 1941}

The only significant flood occurring in the period 1917-64 was that on the Gila River in late September 1941. During the preceding several months, precipitation was much more abundant than usual so the moisture content of the soil was high. Then a storm originating in the Gulf of Mexico resulted in heavy rain on the upper part of the area drained by the Gila River above its confluence with the San Francisco River. Considerable damage was done to farmland in the Virden and Duncan Valleys. At Virden, the bridge over the Gila was 
washed out, and at Duncan the business and residential sections and the approaches to the bridge over the Gila were inundated.

Downstream, at the gaging station at the Gila River near Clifton, the peak discharge was $28,200 \mathrm{cfs}$ on September 29 and, according to Patterson and Somers (1966, p. 394), may have been the highest at that site since 1891. Farther downstream, at the head of Safford Valley and at San Carlos, the peak discharges were $31,900 \mathrm{cfs}$ on September 31 and $27,900 \mathrm{cfs}$ on October 1, respectively-both less than one-third the peak discharge of the recorded maximum flood at those sites. The peak discharge of the San Francisco River at Clifton during this flood was only $7,300 \mathrm{cfs}$.

\section{FLOODS OF DECEMBER 21-24 AND DECEMBER 30-31, 1965}

A succession of storms beginning in late November 1965 contributed to the flooding that occurred December 21-24 and December 29-31 of the same year. (See table 5.) Those of November 22-27, December 8-12, and December 13-18 thoroughly soaked the lowland soils and left a large accumulation of snow on the mountains. Then on December 21-23 warm rain fell at altitudes of as much as 9,000 feet and caused rapid melting of part of the snow cover; the resulting runoff caused the earlier of the two December floods. Within a week another warm rain caused additional melting of the snow and more flooding. All the precipitation associated with these two floods was the result of Tropical storms that originated over the Pacific Ocean and moved eastward across Arizona. Warm rain at such high altitudes and so abundant a moisture supply were highly unusual for the time of year.

TABle 5.-Storm precipitation in November and December 1965 at five U.S. Weather Bureau stations in or near the Gila River basin above Coolidge Dam

\begin{tabular}{|c|c|c|c|c|c|c|}
\hline \multirow{2}{*}{ Station } & \multicolumn{6}{|c|}{ Precipitation (inches) } \\
\hline & $\begin{array}{l}\text { Nov. } \\
22-27\end{array}$ & $\begin{array}{l}\text { Dec. } \\
8-12\end{array}$ & $\begin{array}{l}\text { Dec. } \\
\text { 13-18 }\end{array}$ & $\underset{21-24}{\text { Dec. }}$ & $\underset{29-3 \mathrm{i}}{\text { Dec. }}$ & Total \\
\hline \multicolumn{7}{|l|}{ Arizona: } \\
\hline $\begin{array}{l}\text { Alpine } \\
\text { Clifton }\end{array}$ & $\begin{array}{r}1.55 \\
.90\end{array}$ & $\begin{array}{l}0.11 \\
3.00\end{array}$ & $\begin{array}{l}1.93 \\
1.50\end{array}$ & $\begin{array}{l}0.93 \\
215\end{array}$ & $\begin{array}{r}1.39 \\
.35\end{array}$ & $\begin{array}{l}5.91 \\
7.90\end{array}$ \\
\hline \multirow{3}{*}{$\begin{array}{l}\text { New Mexico: } \\
\text { Fort Bayard. } \\
\text { Lordsurg- } \\
\text { Reserve Ranger Station........ }\end{array}$} & & & & & & \\
\hline & .20 & $\begin{array}{l}1.87 \\
1.40\end{array}-1$ & i. & $: 70$ & .44 & $\begin{array}{l}3.73 \\
4.39\end{array}-10$ \\
\hline & .69 & 2.64 & 1.50 & .95 & .97 & 6.75 \\
\hline & 0.78 & 1.80 & 1.35 & 1.13 & 0.68 & 5.74 \\
\hline
\end{tabular}

Flood-plain developments since the flood of October 1916 contributed to the high cost and nature of the flood damage. Most of the fertile flood plain, stripped of natural vegetation, had been transformed into irrigated cropland through construction of diversion dams, canals, and headgates and by building dikes to protect the cropland from floods. Meanwhile, the river channel and the part of the flood plain not developed for irrigation had become congested with a heavy growth of saltcedar. Not only was the size of the main river channel reduced, but the resistance to flow of water on the flood plain was increased greatly. The reduction in size of channel and the increased resistance to flow of water resulted in a relatively low conveyance capacity for the river. Thus, when the floodwave moved downstream, the conveyance capacity of the channel and bordering undeveloped flood plain was soon exceeded, the dikes broke, and water flowed onto the cultivated fields (fig. 18). As most of the fields had raised borders, they filled until the border either broke or was overtopped at some point, and then the temporarily stored water spilled onto the adjoining lower lying field. Several fields were left with large channels through them, and many of the irrigation canals were breached. During the recession of the first flood, and also during the second flood, the rate of discharge in some of the fields was greater than in the adjoining river channel. Most of the roads on the flood plain were under water, and several were breached. The approaches to the bridges over the Gila River at Solomon, Safford, and Pima were overtopped and closed to traffic for several hours (fig. 18).

The estimated damage to farm real estate in Greenlee County was $\$ 465,000$ (Greenlee County Agriculture Disaster Committee, written commun., January 14, 1966), and in Graham County it was $\$ 1,260,000$ (Joint Graham County and Cities Civil Defense, written commun., January 14, 1966).

The flood damage in eities and small communities in the Gila River basin was relatively small. In the north part of Clifton a few homes were flooded, but in the south part the water did not overtop the walls that had been constructed to protect that part of town from flooding (figs. 19 and 20). Damage to public property in Clifton - sewage systems, roads, and parks - was estimated at $\$ 25,000$ (Tony Rodrigues, mayor of Clifton, written commun., January 28, 1966).

In Safford, the estimated flood damage was $\$ 25,000$ (Joint Graham County and Cities Civil Defense, written commun., January 14, 1966). The damage was mostly to roads, sewers, and water systems. 


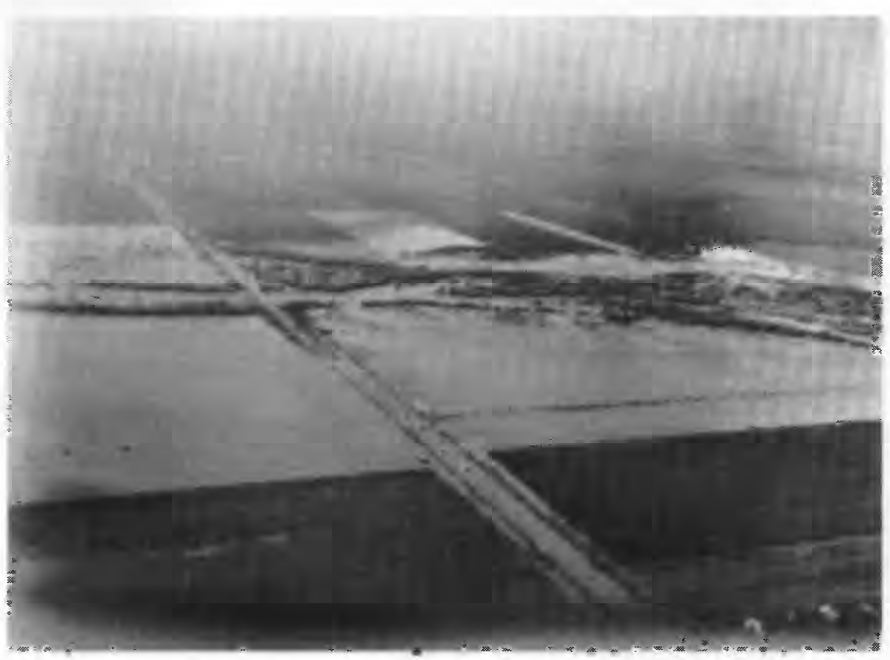

$A$

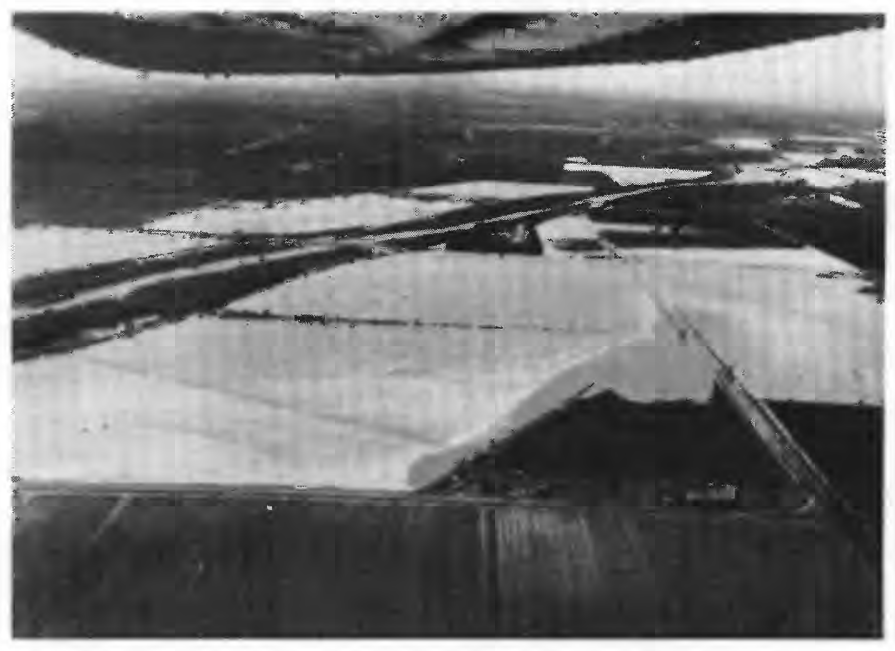

$B$

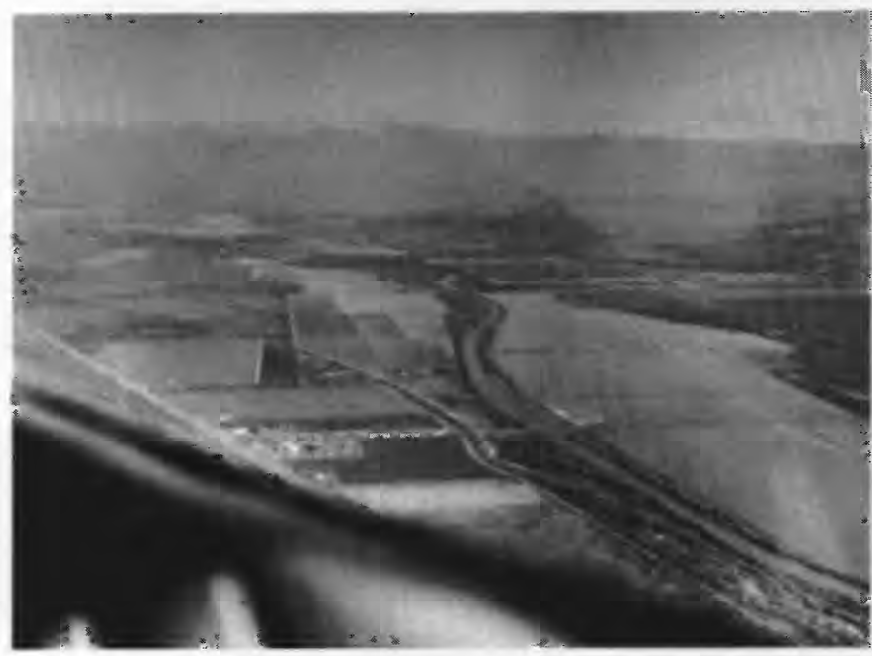

$C$

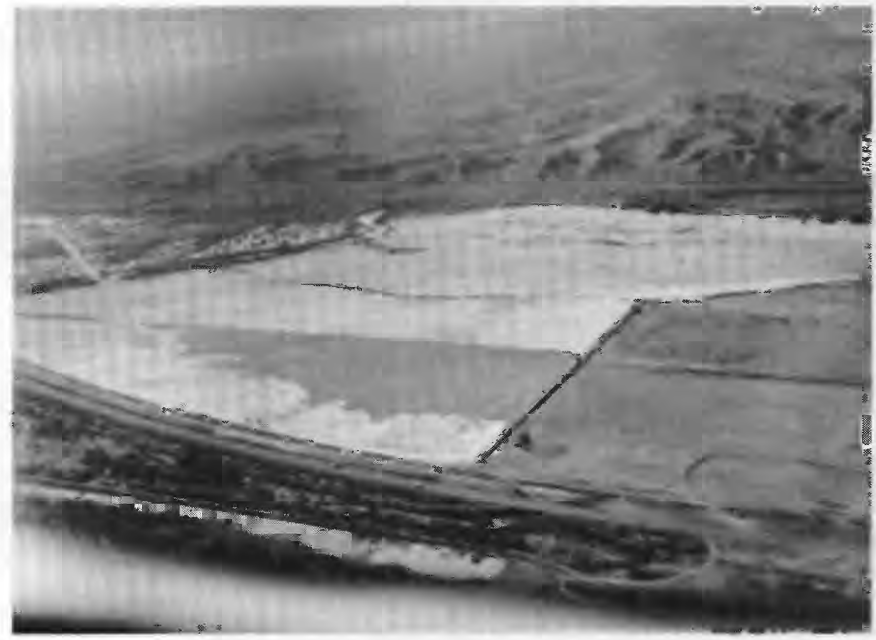

D

Figure 18.-Flood of December 23, 1965, in the Safford Valley. A, Looking south toward approach to the bridge on the Gila River; Safford is in the background. $B$, Looking south and downstream toward the Pima Bridge. $C$, Looking downstream near Pima. $D$, Looking south and downstream across the recently cleared (1965) flood plain in the Gila River Phreatophyte Project area; U.S. Highway 70 is in the foreground, and the foothills of Mount Turnbull are in the background. Photographs furnished by the U.S. Bureau of Land Management, Safford. 


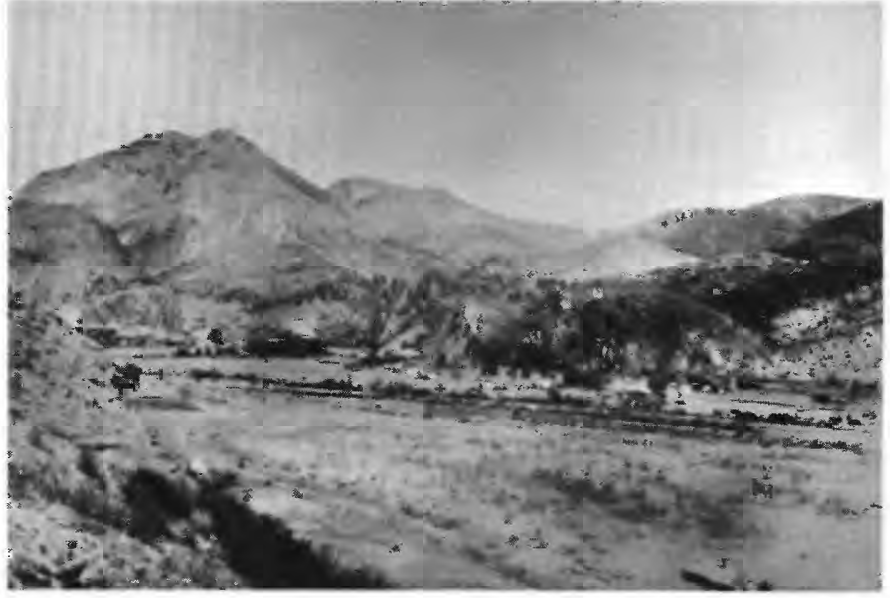

$A$

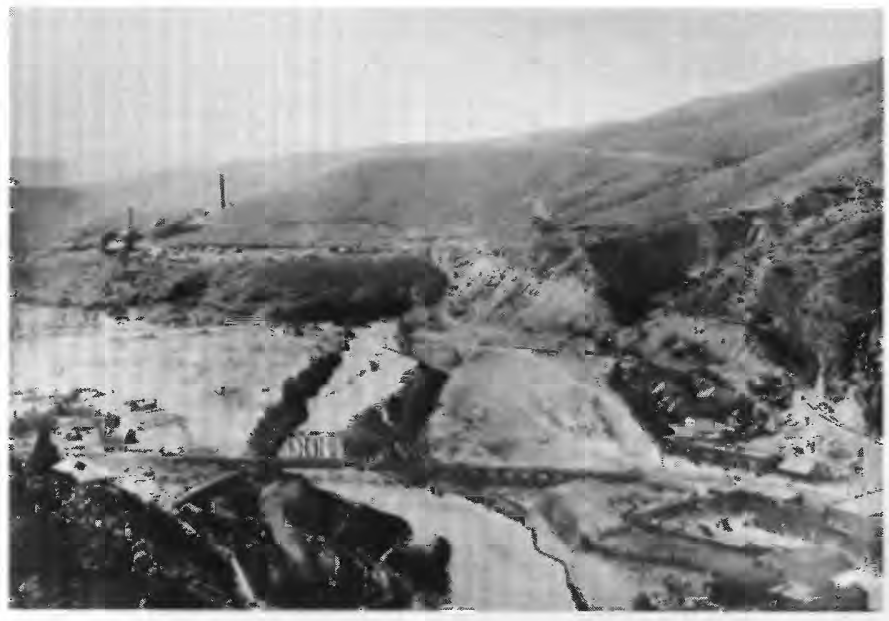

$B$

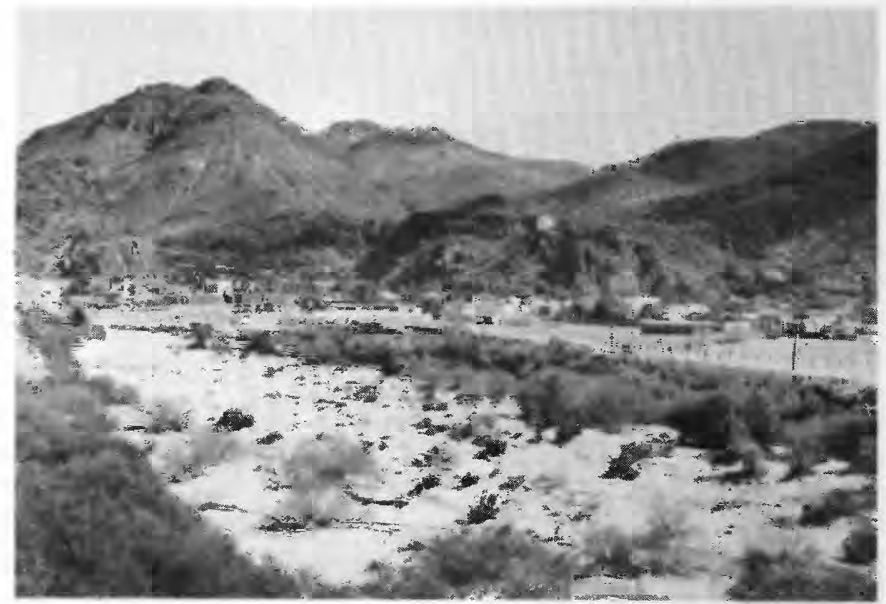

$C$

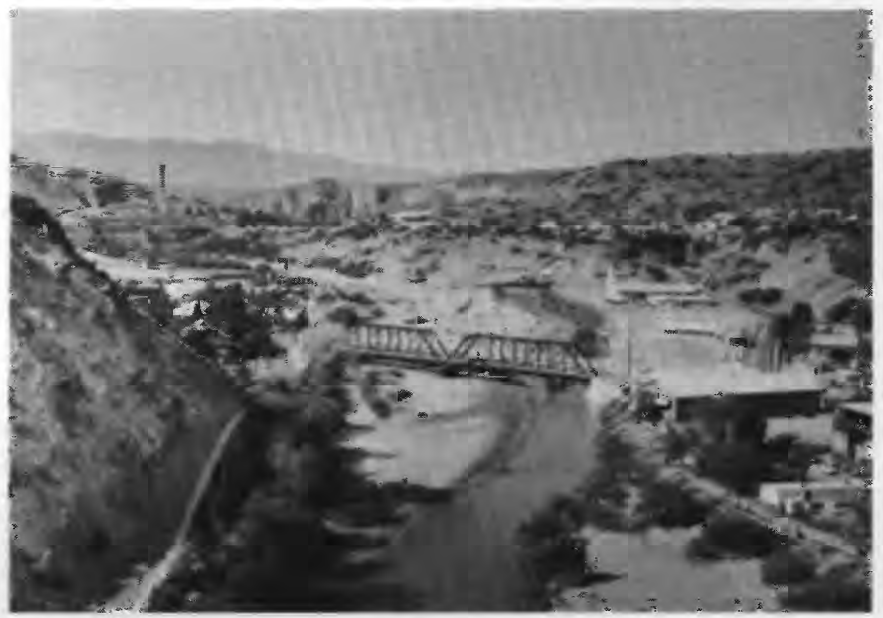

$D$

Figure 19.- San Francisco River flood plain at Clifton. A, Looking upstream toward railroad bridge over the San Francisco River; shows the flood plain prior to 1900 . $B$, Looking downstream toward the railroad bridge; shows the flood plain prior to 1900 . $C$, Looking upstream toward railroad bridge, April 27, 1966. D, Looking downstream toward railroad bridge, April $27,1966$. Photographs furnished by Mr. Charley Brown and Mr. Clarence McBride, Safford. 


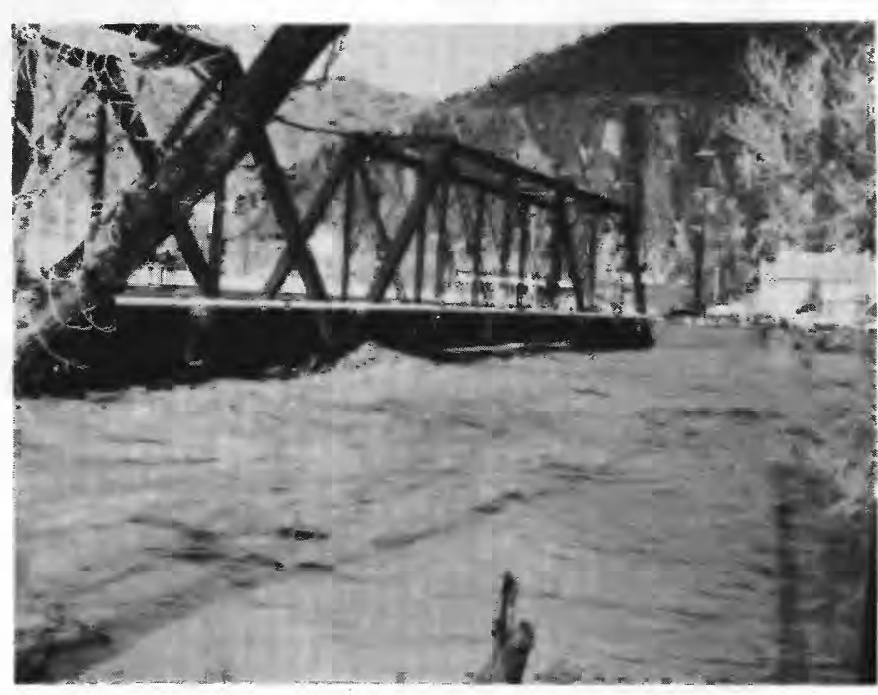

$A$

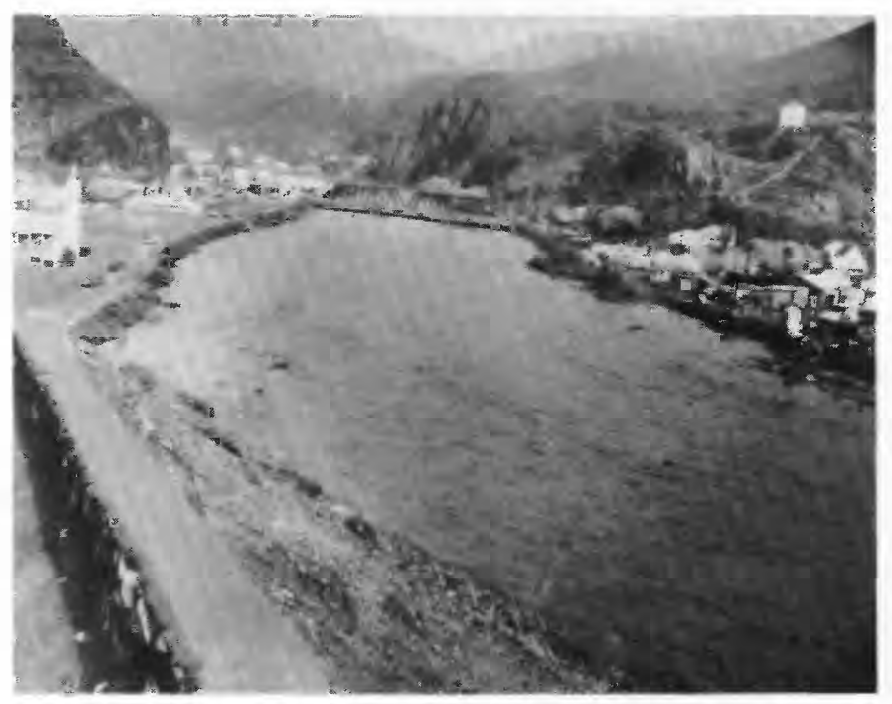

$B$

Frgure 20.-Flood of December 21, 1965, at Clifton. A, Looking downstream and across San Francisco River toward railroad bridge. $B$, Looking upstream toward railroad bridge; the flood dikes were not overtopped in this reach of the river. Photographs furnished by Risdon Studios, Clifton.
Many dwellings in Little Hollywood, a community of about 500 farm workers, were flooded as a result of high flows in the Gila River (fig. 21). Although the community is on the flood plain near the confluence of the Gila and San Simon Rivers, the dwellings did not wash away. Fortunately, the San Simon River carried only a small rate of flow.

The magnitude of damage to rural areas and small communities along the headwaters in the mountains is unknown, but severe damage occurred on several farms and ranches owing to flooding of Bonita and Eagle Creeks and the Blue and San Francisco Rivers. High flows in the San Carlos River flooded several homes in the town of San Carlos.

During the flood of December 21-24, the Gila River at head of Safford Valley peaked three different timestwice on the 23rd and once on the 24th (fig. 22). The first of the three peaks was the greatest, although it preceded the single peak $(30,000 \mathrm{cfs})$ on the San Francisco River at Clifton by 11 hours and the peak on the Gila River near Clifton by 33 hours. Apparently, about $15,000 \mathrm{cfs}$ of the $43,000 \mathrm{cfs}$ peak discharge at the head of Safford Valley was due to tributary inflow to the Gila River below the gaging stations at and near Clifton, as the hydrographs in figure 22 indicate that no more than about 18,000 cfs could have been runoff from above those two upstream stations. The second peak (36,000 cfs) was due, in part, to the floodwave on the San Francisco River, which had crested about $31 / 2$ hours earlier at Clifton, and the third peak $(14,000 \mathrm{cfs})$ was due to the floodwave on the Gila River, which had crested a little less than 4 hours earlier at the gaging station near Clifton.

The peak discharge of $39,000 \mathrm{cfs}$, corresponding to the first peak at the head of Safford Valley, in the Gila River at Calva occurred in the early afternoon of December 24 . The second peak, which occurred at the head of Safford Valley, was not noticeable at Calva. The third peak was barely noticeable at Calva on December 26 .

The peaks of the year-end flood were much lower than those of the flood a week earlier. The San Fran- 


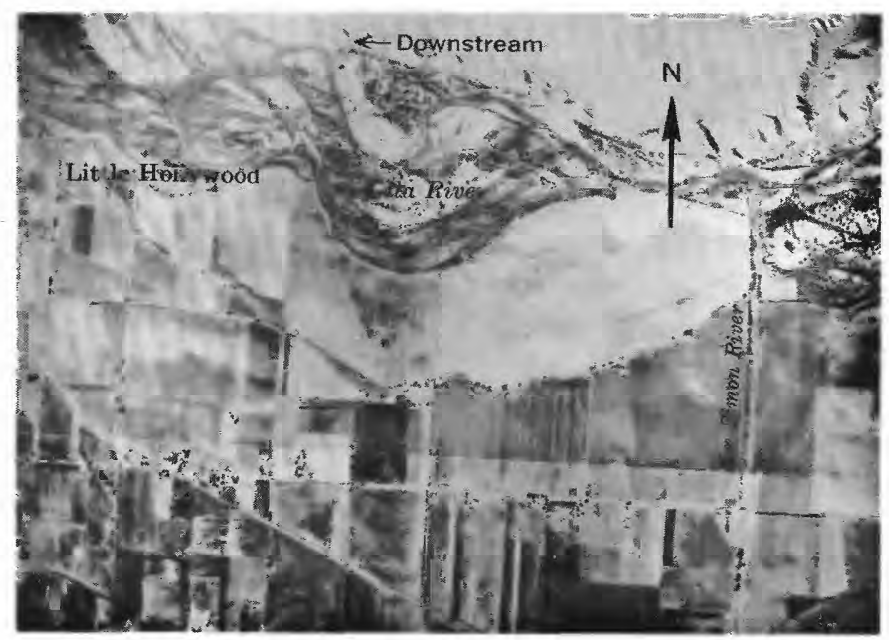

$A$

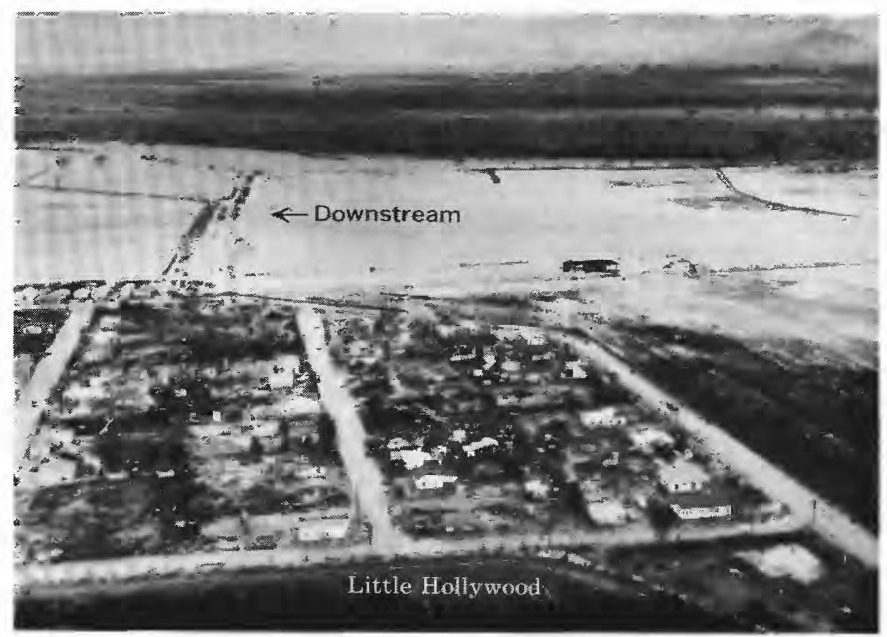

$B$

FIGURE 21.-Gila River flood plain in 1935 and flood of December 23, 1965, at Little Hollywood. A, Aerial photograph of the Gila River flood plain taken in 1935; the intersection of the Gila River, which flows west, and the San Simon River, which flows north, is in the upper right quarter; the site where Little Hollywood is now located is in the upper left quarter. $B$, Flood of December 23, 1965, at Little Hollywood and the flood plain. Photographs furnished by Rogers Studios, Safford. cisco River at Clifton peaked at about 17,000 cfs twice within 12 hours, but the Gila River peaked only once at the gaging stations near Clifton, at the head of Safford Valley, and at Calva. The earlier of the two floodwaves on the San Francisco River was the cause of the single peak at the head of Safford Valley; apparently, the later floodwave on the San Francisco merely caused a slowing of the recession from the single peak on the Gila River at the head of Safford Valley.

According to Patterson and Somers (1966, p. 1-57), the peak flows for December 22-24 at the gages in the San Francisco River at Clifton, Gila River at head of Safford Valley, and the Gila River at Calva have return intervals of about 12,16 , and 17 years, respectively (fig. 23). The return interval for the smaller floods at the same stations on December 30-31, 1965, and January 1,1966 , was about 6 years.

\section{SUMMARY}

In the Gila River basin, precipitation is the result of five types of airmasses: (1) cool moist Polar Pacific from the northern Pacific Ocean, (2) warm moist Tropical Pacific from the southern Pacific Ocean, (3) warm moist Tropical Gulf from the Gulf of Mexico, (4) cold dry Polar Continental from Canada, and (5) hot dry Tropical Continental from Mexico. In the winter the weather usually is the result of types 1 and 4 , but occasionally type 2 brings large amounts of precipitation. Type 5 is predominant in the spring. In the summer the weather usually is the result of type 3 , although type 2 may bring large amounts of precipitation in late September and October. A change in the predominance of an airmass may shift the weather from an average condition. At times the shift is striking, as in 1941 and 1965, when more than a normal number of Tropical Pacific storms brought large amounts of precipitation into the basin and caused large amounts of runoff. The major floods in 1905 through 1916 presumably are the result of shifts in the predominance of the Tropical Pacific airmasses. 


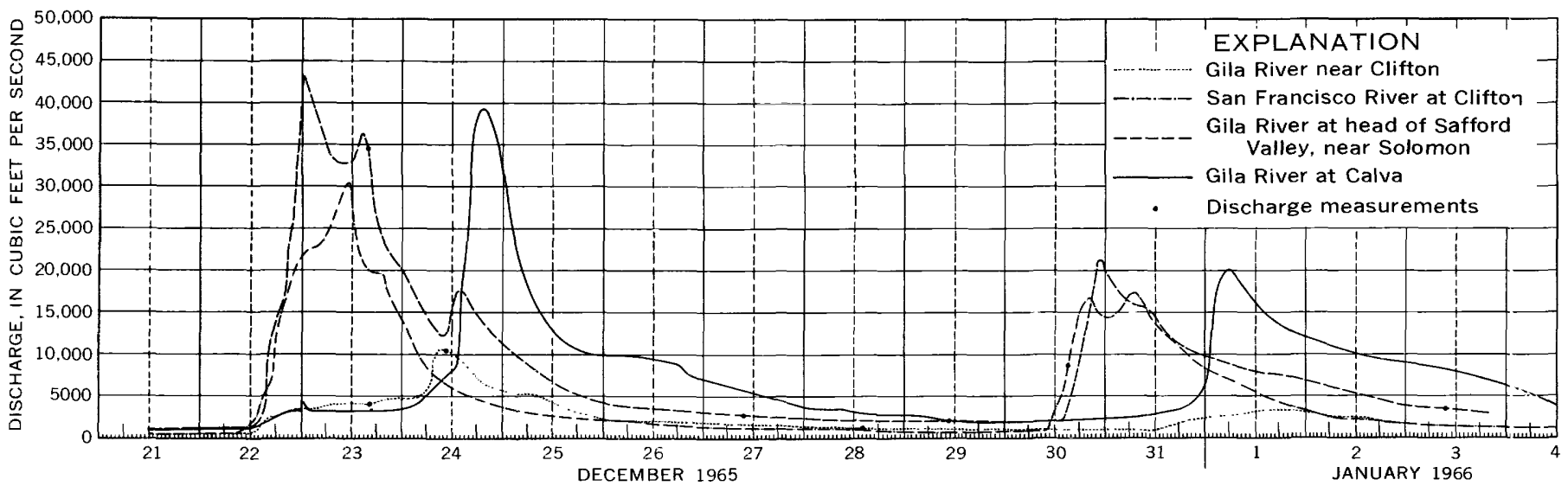

Figure 22.-Floodflows, December 21, 1965, to January 4, 1966.

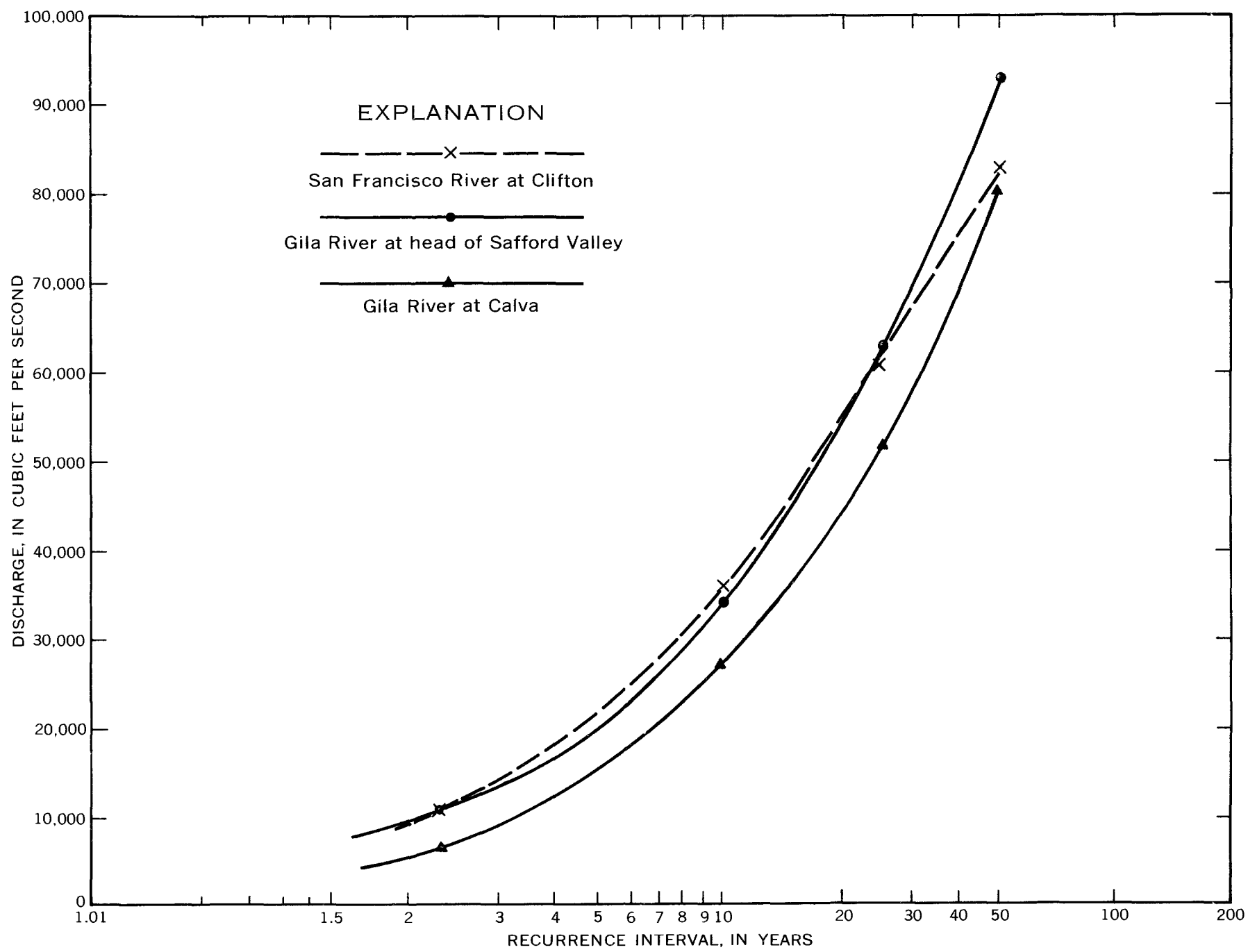

Frgure 23.-Peak-discharge frequency curves for San Francisco River at Clifton, Gila River at head of Safford Valley, and Gila River at Galva. Curves adapted from Patterson and Somers (1966). 
Since 1920, there has been almost continual decrease in the amount of precipitation in the Gila River basin. The decrease has been mainly in winter precipitation, and there has been a parallel decline in winter streamflow. A lower incidence of major floods also has been noted. For example, major floods occurred in nine winters during period 1891-1916, but only one major flood (December 1965) occurred in the period 1917-65. The December 1965 flood in Safford Valley had a peak discharge of $43,000 \mathrm{cfs}$, which had a return interval of about 12 years. The change or decrease in precipitation and runoff is associated with a shift in the predominance of the airmasses that control the climate of the Gila River basin.

In the Gila River basin the summer precipitation is mainly from local convective thunderstorms, which produce rainfall of high intensity and short duration over small areas. The long-term average of summer precipitation at six sites was 7.91 inches, or 57 percent of the average annual precipitation. The means ranged from 5.58 inches in the lower altitudes to 11.61 inches in the mountains, and the coefficients of temporal variation ranged from 0.25 to 0.45 .

Winter precipitation is mainly from convergence, or frontal, storms that distribute moisture over large areas. Owing to the infrequent occurrence of large amounts of precipitation from Tropical Pacific storms, the temporal variability of winter precipitation is larger than that of summer precipitation. The long-term average of winter precipitation at six sites was 4.96 inches, or 36 percent of the average annual precipitation. The means ranged from 3.49 to 7.42 inches, and the coefficients of temporal variation ranged from 0.34 to 0.60 .

The average summer flow (1914-64) past the Gila River at head of Safford Valley gaging station was about 97,300 acre-feet, or 32 percent of the average annual flow. The standard deviation was about 71,300 acre-feet, and the coefficient of variation was 0.71 . The summer flow ranged from 15,700 acre-feet in 1956 to 345,000 acre-feet in 1916 . The highest consecutive 10year average was 164,000 acre-feet per year from 1914 through 1924, and the lowest consecutive 10-year average was 44,800 acre-feet per year from 1943 through 1953. There has been no long-term trend toward reduced summer streamflow.

The average winter flow (1914-64) of the Gila River at head of Safford Valley gaging station was about 210,000 acre-feet, or 68 percent of the average annual flow. The standard deviation was 220,000 acre-feet, and the coefficient of variation was 1.04 . The winter flow ranged from 19,600 acre-feet in 1959 to about 1,180,000 acre-feet in 1916. The highest consecutive 10-year average was 377,000 acre-feet per year from 1914 through
1924, and the lowest consecutive 10-year average was 105,000 acre-feet per year from 1949 through 1959about a 270 percent difference in 10-year averages. Except for the relatively short period $1936-42$, th are was a fluctuating decline in winter streamflow from 1920 through 1962.

Preliminary studies of the relation of runoff to precipitation during the period 1916-64 show no continual decrease in the ratio of the former to the latter. Therefore, the decrease in streamflow after 1920 was mainly due to the decrease in winter precipitation. Studies of the depletion of flow in the Gila River withir the 55mile length of the Safford Valley since 1920 indicate no long-term trend toward greater flow losses. A lthough some small changes in trend may have occurred, they could be detected only by making detailed stidies. A budget of inflow versus outflow for 1938-61 indicates that the average annual surface-water loss in Safford Valley was 112,000 acre-feet, a loss of 2,040 acre-feet per mile per year.

\section{REFERENCES CITED}

Barr, G. W., 1954, Arizona agriculture, 1954: Arizona Univ., Agr. Expt. Sta. Bull. 252, 18 p.

Burkham, D. E., 1966, Hydrology of Cornfield Wash area and effects of land-treatment practices, Sandoval County, New Mexico, 1951-60: U.S. Geol. Survey Water-Supmly Paper $1831,87 \mathrm{p}$.

Burkham, D. E., and Dawdy, D. R., 1970, Error analysis of streamflow data for an alluvial stream: U.S. Gesl. Survey Prof. Paper 655-C. (In press.)

Culler, R. C., 1965, The Gila River Phreatophyte Project: Arizona State Land Dept. Ninth Annual Watershed S rmposium Proc., p. 33-38.

Cushman, R. L., and Halpenny, L. C., 1955, Effect cf western drought on the water resources of Safford Valley, Arizona, 1940-52: Am. Geophys. Union Trans., v. 36, no. 1, p. 87-94.

Dawdy, D. R., 1961, Depth-discharge relations of alluvial streams-discontinuous rating curves: U.S. Geol. Survey Water-Supply Paper 1498-C, 16 p.

Dorroh, J. H., Jr., 1946, Certain hydrologic and climatic characteristics of the Southwest: Albuquerque, New Mexico Univ. Press, 64 p.

Fenneman, N. M., 1931, Physiography of western United States : New York, McGraw-Hill Book Co., 534 p.

Graham County Guardian, 1895, 1896, 1905: Safford, Ariz., issued weekly.

Lippincott, J. B., 1900, Storage of water on Gila River, Arizona : U.S. Geol. Survey Water-Supply Paper 33, 98 f.

McDonald, J. E., 1956, Variability of precipitation in an arid region-a survey of characteristics for Arizone: Arizona Univ. Inst. Atmospheric Physics Tech. Rept. 1. 88 p.

Olmstead, F. H., 1919, Gila River flood control-a report on flood control of the Gila River in Graham County, Arizona : U.S. 65th Cong., 3d sess., Senate Doc. 436, 94 p.

Oltman, R. E., and Tracy, H. J., 1951, Trends in climate and in precipitation-runoff relation in Missouri River lasin: U.S. Geol. Survey Circ. 98, 113 p. 
Patterson, J. L., and Somers, W. P., 1966, Magnitude and frequency of floods in the United States-Part 9, Colorado River basin: U.S. Geol. Survey Water-Supply Paper 1683, 475 p.

Sellers, W. D., ed., 1960, Arizona climate : Tucson, Arizona Univ. Press, $60 \mathrm{p}$.

Smith, Winchell, and Heckler, W. L., 1955, Compilation of flood data in Arizona, 1862-1953: U.S. Geol. Survey open-file report, $113 \mathrm{p}$.

Thomas, H. E., 1962, The meteorologic phenomenon of drought in the Southwest: U.S. Geol. Survey Prof. Paper 372-A, 43 p.

Thomas, H. E., and others, 1963, Effects of drought in the Colorado River basin: U.S. Geol. Survey Prof. Paper 372F, 51 p.
Thornthwaite, C. W., Sharpe, C. F. S., and Dosch, E. F., 1942, Climate and accelerated erosion in the arid and semiarid Southwest, with special reference to the Polacca Wash drainage basin, Arizona : U.S. Dept. Agriculture Bull. 8m, $134 \mathrm{p}$.

U.S. Army Corps of Engineers, 1914, San Carlos Irrigation Project, Arizona : U.S. 63d Cong., 2d sess., H. Doc. 791, 168 p.

U.S. Geological Survey, Surface water supply of the Unit?d States-Part 9, Colorado River basin: U.S. Geol. Surv?y water-supply papers (published annually through 1961; published periodically, 1961 to present).

U.S. Weather Bureau, issued annually, Climatological data, Arizona : U.S. Dept. Commerce. 